\title{
A LONGITUDINAL ANALYSIS OF VIOLENCE AND HOUSING INSECURITY*
}

\author{
Author: $\quad$ Timothy M. Diette \\ Affiliation: Washington and Lee University \\ Address: $\quad$ Department of Economics, Washington and Lee University, Lexington, VA \\ 24450 USA \\ E-mail: $\quad$ diettet@wlu.edu \\ Phone: $\quad+15404588220$ \\ Author: $\quad$ David C. Ribar (corresponding author) \\ Affiliations: University of Melbourne, Australian Research Council Centre of Excellence for \\ Children and Families over the Life Course, and Institute for Labor Economics \\ (IZA) \\ Address: $\quad$ Melbourne Institute for Economic and Social Research, University of Melbourne, \\ Melbourne, VIC 3010 Australia \\ E-mail: $\quad$ david.ribar@unimelb.edu.au \\ Phone: $\quad+61383442794$
}

November 2017

* This paper uses data collected from the Journeys Home project, a longitudinal survey-based study managed by the Melbourne Institute of Applied Economic and Social Research on behalf of the Australian Government Department of Social Services (DSS). The findings and views reported in this paper, however, are those of the authors and should not be attributed to either DSS or the Melbourne Institute. The authors thank the Faculty of Business and Economics at the University of Melbourne and the Melbourne Institute for financial support. They also thank Deborah Cobb-Clark, Chris Flinn, Robert Haveman, participants at several seminars, and two anonymous reviewers for helpful comments. For correspondence, email $<$ david.ribar@unimelb.edu.au>.

This is the author manuscript accepted for publication and has undergone full peer review but has not been through the copyediting, typesetting, pagination and proofreading process, which may lead to differences between this version and the Version of Record. Please cite this article as doi: 10.1111/ecin.12571

This article is protected by copyright. All rights reserved. 


\begin{abstract}
This study uses national longitudinal data from the Journeys Home survey to examine how violence and housing insecurity in one period affect disadvantaged Australians' chances of experiencing violence and housing insecurity in subsequent periods. Men experience much higher rates of violence and housing insecurity than do women. Our analyses show that housing insecurity in one period increases men's and women's subsequent risks of housing insecurity and that violence in one period increases their subsequent risks of violence. However, the multivariate results provide no evidence of one-period cross-over effects for women and only limited effects for men. (J1, R2)
\end{abstract}

Keywords: Housing insecurity, homelessness, violence, Journeys Home survey, Australia 
Being a victim of physical violence and losing one's accommodation are each deleterious events. Physical violence is painful and in extreme instances can inflict disabling injuries and emotional trauma. Housing insecurity is also detrimental, with harms that range from anxiety over the uncertainty of housing to the intense hardship of being homeless altogether. Worse, each condition may contribute to the other. Domestic violence could force victims to abandon their accommodations; indeed, domestic violence is cited as a leading cause of women's and children's homelessness (Jasinski et al., 2005; Flinders Institute for Housing, Urban and Regional Research, 2008). Violence may also lead to housing problems through stress reactions that impair victims' abilities to function in social or economic settings (Williams \& Mickelson, 2004). Similarly, primary homelessness (being without shelter altogether) deprives people of the physical security associated with shelter, possibly increasing the risk of victimization (Burt et al., 2001; Wenzel et al., 2001), and other marginal housing situations may put people in crowded or compromised conditions where they are vulnerable. The harms and presumed interlinkages of these problems have prompted national plans to reduce violence, including the Australian government's $\$ 100$ million women's safety package, the 2010 Call to End Violence against Women and Girls in the U.K., and Healthy People 2020 in the U.S., and homelessness (Commonwealth of Australia, 2008; U.S. Interagency Council on Homelessness, 2015).

Despite ample evidence that violence and housing insecurity are related, researchers have not convincingly established that either problem causes the other. An obstacle to developing causal evidence has been the lack of large representative samples of people who are at risk of housing problems and who have suffered violence. Many large surveys-including many focused on disadvantaged people — only interview householders. Other surveys of people who are homeless or housing insecure rely on narrow and selective groups, such as shelter residents, 
homeless youth, or people from a single city. Another problem has been researchers' inability to account for the many other characteristics that contribute to violence and housing insecurity and might give rise to spurious correlations. Finally, researchers have rarely had access to prospective longitudinal data that can indicate which events precede others and distinguish antecedents from consequences.

This study overcomes these problems, using national longitudinal data from the Journeys Home $(\mathrm{JH})$ survey to examine how violence and housing insecurity in one period affect disadvantaged Australians' chances of experiencing violence and housing insecurity in subsequent periods. The JH survey interviewed 1,682 Australians who were initially homeless or at high risk of homelessness, asking about their housing, economic, health, and other circumstances, including their experiences with violence, through six semi-annual survey waves from 2011 until 2014. The survey includes a rich set of covariates that we include in multivariate analyses to control for observed characteristics that might confound the estimated relationship between violence and housing insecurity. The survey's longitudinal design allows us to track how experiences with violence and housing problems at one interview relate to these same problems in the next interview, helping to establish a temporal ordering of events. The longitudinal design also allows us to estimate statistical models that account for time-invariant unobserved characteristics that might be sources of bias.

The JH survey has other valuable features. First, unlike many surveys meant to address housing insecurity, $\mathrm{JH}$ interviewed a relatively diverse, albeit disadvantaged, population that included people who were and were not suffering from housing problems and followed them as they transitioned between different housing situations. Second, the survey was national in scope and included people in urban and rural contexts and from each of Australia's states and major 
territories. Third, the large sample size supports the inclusion of numerous controls in our statistical analyses and allows us to conduct separate analyses for men and women.

Fourth, the Australian context itself is interesting. Australia is a prosperous country with extensive social supports. Australia defines homelessness more broadly than the U.S. to not only include people who are on the streets or in emergency shelters but also to include people who are temporarily doubled-up rent-free with friends or family and people living in socially unacceptable accommodations, such as hotels or rooming houses. The Australian Bureau of Statistics (ABS) estimated that 0.5 percent of Australians were homeless at the time of the 2011 census (ABS 2012), and Chamberlain and Johnson (2015) estimated that about an eighth of Australian adults have experienced homelessness during their lifetimes. Another aspect of the Australian context is the availability of cash transfer payments for homeless people. The Australian Institute of Health and Welfare (2012) reported that 82 percent of Australians entering homelessness services in 2011-12 were receiving government payments as their main income. Australia also has universal health insurance. These features contrast with the U.S. where social supports are weaker and where many homeless adults fall through the social safety net.

Our consideration of how men's experiences with violence contribute to their housing problems is especially distinctive. Many studies document how domestic violence is associated with women's and children's subsequent homelessness (e.g., Bassuk et al., 2001; Flinders Institute for Housing, Urban and Regional Research, 2008; Weitzman et al., 1990). Studies also show that homeless men and women suffer higher rates of victimization than their housed counterparts (Burt et al., 2001; Jasinski et al., 2005; Lam \& Rosenheck, 1998; Lee \& Schreck, 2005; Wenzel et al., 2001). However, less is known about how violence might trigger men's housing problems. Although men are less frequently the victims of sexual and domestic violence 
(Breiding et al., 2014), they experience more violence overall than women (see, e.g., Truman \& Langdon, 2015). As we show, disadvantaged Australian men in the JH survey are four percentage points (29 percent) more likely to experience violence in a six-month interval than women, and our multivariate analyses indicate that $\mathrm{JH}$ men who experience violence but are initially housing secure are 10 percentage points more likely to be housing insecure six months later than similar men who do not experience violence. In contrast, our multivariate analyses provide little evidence that violence contributes to women's near-term housing insecurity, although there is evidence of longer-term associations.

In addition, the paper addresses a key conceptual issue in housing security research regarding the centrality of life shocks. O'Flaherty $(2004 ; 2010)$ has theorized that homelessness is often unpredictable and frequently the result of negative, bad-luck shocks hitting people who were otherwise vulnerable. Research has found supporting evidence regarding shocks from income losses (O’Flaherty, 2009), a partner's incarceration (Geller \& Franklin, 2014), and the birth of children with severe health problems (Curtis et al., 2013). Physical violence, which occurs infrequently and unpredictably for the vast majority of people, has properties of a shock.

\section{PREVIOUS STUDIES}

\section{$\underline{\text { Predicting Housing Problems }}$}

Researchers and policymakers have long debated the relative importance of structural and background circumstances on the one hand and individual behaviors and agency on the other as causes of housing insecurity. With respect to structural circumstances, research points to the deinstitutionalization of the mentally ill (Jencks, 1994), limited availability of low-cost housing (Burt, 1991; Quigley et al., 2001; Quigley \& Raphael, 2001), and low levels of economic activity and opportunities (Burt, 1991; Gould \& Williams, 2010) as contributors. Background risk factors 
include being a victim of violence or abuse as a youth (Baron, 2003; Bassuk et al., 2001; Burt et al., 2001; Caton et al., 2005; Herman et al., 1997), having a parent who was incarcerated (Shelton et al., 2009) or used drugs (Bassuk et al., 1997), growing up in poverty (Koegel et al., 1995), spending time in foster care (Burt et al., 2001; Shelton et al., 2009), and poor mental health in childhood (Shelton et al., 2009).

There is also evidence regarding the role of agency, including the abuse of drugs and alcohol (Bassuk et al., 1997; Early, 2005; McVicar et al., 2015; Shelton et al., 2009; Shinn et al., 1998). Joblessness (Shelton et al., 2009; Shinn et al., 1998) and low levels of schooling (Lehmann et al., 2007; Shelton et al., 2009) also contribute to housing problems.

Housing insecurity may itself increase the risks of subsequent housing problems if it compromises people's physical health (Dennis et al., 1991), mental health (Hodgson et al., 2013) or labor market productivity (Glomm \& John, 2001) and lowers their economic prospects. As homeless people come to identify with being homeless, they may take fewer steps to escape their condition or become more accepting of behaviors that prolong their homelessness (Snow \& Anderson, 1987). Several studies have found evidence of state dependence in housing problems (Allgood \& Warren, 2003; Piliavan et al. 1996; Shinn et al., 1998); however, an analysis of the JH survey by Cobb-Clark et al. (2016) detected little evidence of duration dependence within homelessness spells beyond the first two or three months of a spell.

While studies have identified many characteristics that increase the general risks of housing problems, they have been less successful in predicting specific transitions to or from housing insecurity (Shinn et al., 2001). Recognising the unpredictability of homelessness episodes, O'Flaherty $(2004 ; 2010)$ hypothesized that homelessness results mainly from bad-luck shocks striking vulnerable people. In an empirical analysis, O'Flaherty (2009) found evidence 
that income shocks were a principal source of housing insecurity. Curtis et al. (2013) found that shocks in the form of the birth of a child with a severe health problem increased the risks of homelessness, while Geller and Franklin (2014) found that a partner's incarceration contributed to homelessness.

Violence may be another such shock, and domestic violence is regularly cited as a cause of women's housing problems. Violence may have a direct effect if victims have to flee their accommodations. In interviews with homeless women in the U.S., Jasinski et al. (2005) reported that one-in-four told them that violence in their last residence was a cause for their homelessness, and in an analysis of administrative data from Australia, the Flinders Institute for Housing, Urban and Regional Research (2008) found that one-in-three women listed domestic violence as a reason for seeking housing services. Exposure to violence could also have indirect effects through increased stress and anxiety, overstimulation of the allostatic systems, and posttraumatic stress disorder (Basile et al., 2004; McEwan, 1998; Williams \& Mickelson, 2004).

Many homeless women report being previously exposed to violence (Fischer, 1992; Jasinski et al., 2005; Wenzel et al., 2001). Although this suggests that violence causes homelessness, it does not compare homeless people with similar at-risk, housed groups, who might also have high rates of earlier victimization. Studies that have used matched comparison designs have been equivocal. Bassuk et al. (2001) found that intimate partner violence raised the odds that newly homeless mothers would repeat their homelessness episodes; however, Brown and Bassuk (1997) did not find significant differences in victimization between homeless mothers and a housed comparison group. Shinn et al. (1998) and Weitzman et al. (1990) found higher earlier exposure to violence among families that entered homeless shelters relative to those that remained housed, but Lehmann et al. (2007) and Shelton et al. (2009) failed to find 
differences.

Predicting Violent Victimization

General rates of violent victimization are low. In Australia in 2013-14, 2.3 percent of adults reported being physically assaulted in the previous year. ${ }^{1}$ In the U.S., 0.9 percent of people aged 12 and over reported being physically assaulted in 2014 (Truman \& Langton, 2015). While everyone faces some risk of victimization, people of lower socioeconomic status (Hotaling \& Sugarman, 1990) and homeless people face much higher risks (Burt et al., 2001; Fischer, 1992; Garland et al., 2010; Geissler et al., 1995; Kipke et al., 1997; Lam \& Rosenheck, 1998; Lee \& Shreck, 2005; Wenzel et al., 2001).

Conceptual approaches to victimization attempt to identify sources of marginalization to explain why people might be vulnerable. Lee and Schreck (2005) proposed how homelessness and other associated characteristics, including divorce, poverty, poor mental health, and a history of childhood abuse, increase marginalization. The lifestyle-exposure theory of personal crime suggests that homeless people may cope with their circumstances by adopting lifestyles and activities that increase their risks of victimization (Hindelang et al., 1978). People may also experience violence because they initiate physical conflicts (Ruback et al. 2014).

Prior victimization may also increase the chances of subsequent victimization. Chu (1992) discussed repetition compulsion, post-traumatic stress syndrome, and problems relating to others as explanations for revictimization. Violence may also undermine perceptions of agency and self-efficacy (Bandura, 1997; Gecas, 1989). Empirical evidence of associations over time

\footnotetext{
${ }^{1}$ Australian Bureau of Statistics, " 4530.0 - Crime Victimization, Australia, 2013-14,” $<$ http://www.abs.gov.au/AUSSTATS/abs@.nsf/Lookup/4530.0Main+Features12013-14>, released 17 Feb. 2015.
} 
includes findings that sexual abuse as a child correlates with higher risks of sexual assault in college years (Gidycz et al., 1995). Additionally, analyses of panel data have shown that women who suffer partner violence at one point in time are more likely to be victimised again (Frias \& Angel, 2007; Tauchen \& Witte, 1995). Other panel studies show similar results for crime revictimization among young adults (Lauritsen \& Quinet, 1995; Ruback et al., 2014). Ruback et al. (2014) further investigated how substance abuse, depression, and offending behavior mediate revictimization. They found evidence of direct and mediated effects of prior violence on subsequent violence for young men but only evidence of mediated effects for women.

As this discussion indicates, previous research provides evidence of contemporaneous and dynamic links between violence and housing insecurity. However, some of the evidence comes from analyses that only considered homeless people and that relied on implicit comparisons. Other studies that have directly examined comparison groups have used small and select samples. The comparison studies have also typically used cross-section data that include retrospective reports and that sometimes fail to indicate the timing of violent incidents and housing problems. Most studies also lack controls for unobserved characteristics that could lead to spurious associations. Results from some previous studies have been equivocal.

\section{ANALYSIS DATA FROM THE JOURNEYS HOME SURVEY}

Our empirical analyses use data from the six waves of the Journeys Home survey. JH is a large interviewer-administered survey that followed a national sample of Australian public assistance clients who were initially either housing insecure or at risk of housing insecurity. ${ }^{2} \mathrm{We}$

\footnotetext{
${ }^{2}$ As mentioned, most homeless Australians receive government assistance, so assistance rolls provide a good sampling frame. $\mathrm{JH}$ sampled people who received payments any time during the
} 
use the term "housing insecure" to include people who are homeless under Australia's broad definition of homelessness (ABS 2012) and people who are doubled up temporarily with friends and relatives but possibly paying rent. Because it sampled an at-risk population and not just a housing insecure one, the $\mathrm{JH}$ survey is exceptionally valuable for examining the causes and consequences of housing insecurity (see the review by Ribar 2017). Interviews began in 2011 and continued in six-month intervals with each wave asking about people's housing, economic, health, and other circumstances, including their experiences with violence (see Wooden et al., 2012). In the initial survey wave, 1,682 people participated, which represented a response rate of 62 percent of the in-scope sample. Retention in subsequent waves was high, with $91,88,87,85$, and 84 percent of the initial respondents being re-interviewed in waves 2-6, respectively (Bevitt et al., 2014). Many factors contributed to the high retention rates, including the short (semiannual) follow-up periods, the continuity and strong skill set of the interviewers, mailers and other contact activities between waves, the availability of accurate contact data from the public assistance records, the collection of reapproach information at the end of each interview, and the use of incentives.

\section{$\underline{\text { Violence and Housing Insecurity }}$}

In each wave, the JH survey asked, "has anyone used physical violence or force against you in the last six months?" We code a binary indicator that equals one if the person answered "yes" and use this as our principal measure of violence. ${ }^{3}$ The JH survey also asked about the

four weeks prior to May 27, 2011, so it also considered people who had recently left assistance.

${ }^{3}$ These questions are preceded by a statement, "we know these questions may be sensitive, so we can move to a quieter place or skip them if they make you feel uncomfortable," and by a request for consent to continue. Just under four percent of respondents declined to answer the violence 
characteristics of violence, including whether the person experienced multiple episodes, the relationship to the assailant, whether the person was physically harmed, and whether the person experienced anxiety or fear because of the incident. We conduct descriptive analyses using these measures to provide a clearer picture of the violence suffered by the respondents.

In addition to questions about physical violence, the JH survey also asked about experiences in the last six months with sexual assault and with being "the victim of an assault or robbery which resulted in police contact or investigation." In sensitivity analyses, we examine alternative measures of victimization that combine experiences of (a) either physical violence or sexual assault and (b) either physical violence or a reported assault or robbery.

To indicate housing insecurity, we use a binary measure that is supplied with the JH data that takes on a value of one if a person

a) experienced primary homelessness (e.g., was sleeping rough, slept in a car, or squatted in an abandoned building)

b) was living in a caravan/camper, hotel, boarding house, or crisis accommodation, or

c) was living temporarily with friends, family, or other relatives

at any time during either the six months before the wave 1 interview or during the time between subsequent interviews. Our six-month measure is similar to the ABS (2012) measure of homelessness, which includes primary homelessness, staying temporarily rent-free in accommodations with friends or relatives or in emergency shelters, and living in

questions. Women, people who identify as Aboriginal or Torres Strait Islanders, migrants from non-English-speaking countries, people diagnosed with psychological conditions, and people living outside of major cities had lower response rates, while married people and disabled people had higher response rates. Response rates also increased over the course of the survey. 
accommodations that fail to meet community standards. However, our measure also includes situations where people lived short-term with friends or relatives but paid rent.

In sensitivity analyses we also consider a narrower measure of "literal homelessness," which we defined as spending any time during the months preceding the interview sleeping rough or squatting in an abandoned building (primary or unsheltered homelessness) or any time in emergency accommodations (sheltered homelessness). The literal homelessness measure aligns with the definition the U.S. Department of Housing and Urban Development (e.g., U.S. HUD, 2016) uses in statistical reporting.

\section{Explanatory Variables}

Our empirical analyses incorporate many explanatory variables from the JH survey. Most importantly, we include lags of people's housing insecurity and violence outcomes so that we can examine how experiencing these outcomes in one wave affects the chances they occur in the next. Specifically, we use a four-category lagged measure that interacts the different possible combinations of housing insecurity and violence: securely housed and no violence (the reference category), insecurely housed and no violence, securely housed and violence, and insecurely housed and violence. The use of lagged dependent variables allows us to investigate whether housing insecurity and violence are subject to state dependence and cross-lag effects - that is, whether previous violence predicts subsequent homelessness and vice versa. The interacted categorization further allows us to examine whether particular combinations of conditions are important.

Gender is another key conditioning variable. Johnson et al. (forthcoming) have found that many aspects of homelessness are gendered. Preliminary analyses of our data indicated that the rates and characteristics of violence and housing insecurity differed substantially between men 
and women. Accordingly, we disaggregate all our analyses by gender.

Our other background controls include measures for whether the respondent identified as Aboriginal or a Torres Strait Islander; migrated from a non-English-speaking country; was lesbian, gay, or bisexual; did not live with both biological parents at age 14; lived in foster, residential, or kin care as a child; and was ever incarcerated prior to the JH survey.

We also incorporate background controls for experiences of housing problems, violence, and victimization in childhood or as an adult prior to the $\mathrm{JH}$ survey. We include an indicator for being homeless before age 18 . We created a 0-4 index of childhood abuse and neglect that is the sum of indicators for whether the person's childhood included being left without food or shelter, suffering physical force or violence from someone s/he lived with, suffering physical force or violence from someone else, and being sexually assaulted. ${ }^{4}$ In addition, we included an indicator for whether the person declined to answer questions regarding sexual violence. We also include indicators for whether the person was ever homeless and whether the person ever experienced physical violence as an adult prior to the JH survey.

We include several contemporaneous time-varying measures that are arguably exogenous, including a quadratic for the person's age; three dummy variables for education (completing years 10-11, completing year 12, or completing a university degree - the omitted category is completing less than 10 years of school); and dummies for each $\mathrm{JH}$ wave.

Because our other time-varying explanatory variables are potentially impacted by housing insecurity or violence, we incorporated lagged, rather than contemporaneous, measures of them. These include indicators for living either in a small city or in a rural or boundary area

\footnotetext{
${ }^{4}$ Preliminary analyses revealed that allowing for separate effects of the abuse and neglect experiences did not improve the explanatory power of the models by much.
} 
(the omitted category is living in a large city); an indicator for being in a formal or de facto marriage; the number of children under 18; the logarithm of the person's gross income; an indicator for being employed; a 1-5 self-assessment of poor health, an indicator for having a long-term health or disability condition; the Kessler scale (0-24) of psychological distress; an indicator for ever being diagnosed with a psychological disorder; the number of days in the previous month the person had five or more alcoholic drinks; an indicator for marijuana use; an indicator for being incarcerated during the survey wave; an indicator for being in contact with family; and indicators for having employed friends, homeless friends, and friends who used drugs, were in prison, or were arrested. We also created indicators for whether information for the person's income, disability status, psychological diagnosis, or drinking behavior were missing.

To control for housing costs and job market conditions, we use a lagged measure of the person's SA4 area of residence to link each observation to the log of the area apartment/flat rental price and the area unemployment rate for the observation reference period. We use lagged information to identify areas because we are considering a highly mobile population and people's location outcomes may be endogenous. We use current information to characterize the conditions at these locations because the current conditions should be relevant and exogenous. ${ }^{5}$

To address issues associated with selective attrition, we include a time-varying indicator for whether the person is a non-respondent or had his or her observation dropped in the subsequent wave.

\footnotetext{
${ }^{5}$ SA4 areas are sub-state geographies defined by the Australian Bureau of Statistics to represent labor sub-markets; they have 300,000-500,000 people in metropolitan areas and 100,000300,000 people in other areas.
} 
Besides these measures, we experimented with including measures for the person's childhood home environment, work experience, availability of social supports, use of street drugs, and full-time employment. However, these measures were never significant for either men or women, and their inclusion did not alter our other findings.

\section{Analysis Sample}

We initially selected wave-specific observations for people who participated in the interviews (dropped attriters), were at least 18 and less than 70 years old, and completed the interviews without the assistance of others, eliminating 2,114 of the potential $10,092(=1,682 \mathrm{x}$ 6) person-wave observations. We then dropped 389 observations with missing information on housing insecurity or violence status. We next dropped 1,855 observations that either were missing information for the explanatory variables (except those noted as having missing flags) or that followed a break in the longitudinal sequence (e.g., if a wave 4 observation was deleted, we dropped the wave 5 and 6 observations). Our final analysis sample has 5,734 person-wave (1,259 individual) observations. Of these, we use 1,259 observations from wave 1 in our "initial conditions" models and 4,475 observations (2,486 for men and 1,989 for women) from waves 2 6 in our lagged dependent variable models. Means of the explanatory measures for our longitudinal analysis sample calculated separately by gender are reported in Appendix A.

\section{THE INCIDENCE AND CHARACTERISTICS OF VIOLENCE AND HOUSING INSECURITY}

We begin our empirical analysis by tabulating how the rates and characteristics of violence and housing insecurity vary with each other. The top panel of Table 1 lists the 
percentages of men and women who experienced different violence outcomes. Rates of physical violence among $\mathrm{JH}$ respondents were much higher than for Australians generally, with 18.8 percent of men and 14.6 percent of women reporting incidents in the six months preceding their interviews. For both men and women, the incidence of violence was approximately 10 percentage points higher if they were housing insecure than if they were housing secure.

Among people who reported violence, women were more likely than men to report being harmed, experiencing fear or anxiety, and being a romantic partner of the assailant, while men were more likely to report multiple violent events and being assaulted by strangers. The results confirm the salience of intimate partner violence for women, with partners accounting for 56.9 percent of women's violent episodes. Men and women who were housing insecure were twice as likely to report experiencing multiple violent episodes as those who were housing secure. The relationships with assailants differed for women conditional on their housing security, with housing insecure women reporting more former-partner violence. Housing insecure women also more frequently reported being harmed by their violence episodes than housing secure women.

Sexual assault is far rarer in the JH survey than physical violence; just under three percent of women and one percent of men indicated that they had been sexually assaulted. As with physical violence, the rates of sexual violence in the JH survey are several times those among Australians generally, which are estimated to be 0.5 percent yearly for women and 0.1 percent for men. ${ }^{6}$ Housing insecure women were nearly three times more likely than housing secure women to report being sexually assaulted.

\footnotetext{
6 “4530.0 - Crime Victimization, Australia, 2013-14," $<$ http://www.abs.gov.au/AUSSTATS/abs@.nsf/Lookup/4530.0Main+Features12013-14>, released 17 Feb. 2015).
} 
Gender differences also appeared in respondents' housing experiences, with men being more likely to be housing insecure. Men spent more time without shelter, more time in socially unacceptable housing (caravans, boarding houses, crisis accommodations), and less time in own housing. Among the men and women who experienced housing insecurity, there were relatively few differences in housing characteristics conditional on violence.

In Table 2, we consider the longitudinal relationships among the housing insecurity and violence outcomes. The top panel shows the probabilities of men being housing insecure and experiencing violence in the six months preceding their interviews conditional on their experiences with different housing and violence outcomes in the prior interview. It also shows the marginal differences in current housing insecurity and violence risks for each combination of lagged conditions relative to previously being housing secure without experiencing violence. The bottom panel displays the same probabilities and marginal differences for women. The probabilities that someone is housing insecure or experiences violence in one period are each much higher if the person experienced housing insecurity, violence, or both in the previous period. All the estimated marginal differences are statistically significant.

The unconditional associations are consistent with state dependence. Men's risks of housing insecurity are estimated to be 54 to 55 percentage points higher if they previously experienced housing insecurity; women's risks are 39 to 47 percentage points higher. Men's risks of experiencing violence are 31 to 34 percentage points higher if they previously experienced violence, while women's risks are 23 to 32 percentage points higher.

There is also evidence of cross-lag correlations. Violence in one period is associated with a higher risk of housing insecurity in the next. Among men, however, this association only holds for those who were initially housing secure—violence adds little to the risk of housing problems 
among men who were initially housing insecure. Similarly, housing insecurity in one period is associated with more violence in the next, though the association is weaker for men who had previously experienced violence. The differences in the interacted associations for men prompt us to include compound, rather than simple, controls for lagged housing and violence outcomes in our multivariate models.

\section{MULTIVARIATE EMPIRICAL ANALYSES}

\section{$\underline{\text { Probit Models }}$}

To move beyond simple associations, we estimate multivariate probit models. Let $H_{i, t}{ }^{*}$ denote person $i$ 's latent propensity to be housing insecure at wave $t$, and let $V_{i, t}{ }^{*}$ denote the person's latent propensity to experience violence. We model each latent propensity as depending on the person's four-category, compound housing insecurity and violence status from the previous wave, $H V_{i, t-1}$, observed exogenous time-varying characteristics in the current wave, $X_{i, t}$, observed endogenous time-varying characteristics from the previous wave, $S_{i, t-1}$, and observed time-invariant characteristics, $Z_{i}$. We also assume that $H_{i, t}{ }^{*}$ depends on a time-varying unobserved variable, $\varepsilon_{i, t}{ }^{*}$, and that $V_{i, t}{ }^{*}$ depends on a time-varying unobserved variable. $v_{i, t}{ }^{*}$. The probit specifications are

$$
\begin{gathered}
H_{i, t}{ }^{*}=\beta_{L}{ }^{\prime} H V_{i, t-1}+\beta_{X}{ }^{\prime} X_{i, t}+\beta_{S^{\prime}} S_{i, t-1}+\beta_{Z^{\prime}} Z_{i}+\varepsilon_{i, t}{ }^{*} \\
V_{i, t}{ }^{*}=\delta_{L}{ }^{\prime} H V_{i, t-1}+\delta_{X}{ }^{\prime} X_{i, t}+\delta_{S^{\prime}} S_{i, t-1}+\delta_{Z}{ }^{\prime} Z_{i}+{v_{i, t}}{ }^{*}
\end{gathered}
$$

for $t=2,6$ and where the $\beta$ and $\delta$ terms represent vectors of coefficients. The person is housing insecure, $H_{i, t}=1$, if $H_{i, t}{ }^{*}$ is positive and experiences violence, $V_{i, t}=1$, if $V_{i, t}{ }^{*}$ is positive. Coefficient estimates and selected marginal effects from these models are reported in Table 3.

The estimated associations between the lagged and current housing insecurity and violence outcomes from the probit models are similar to the unconditional estimates from Table 
2 , though the magnitudes of the marginal differences are smaller. For men, experiencing housing insecurity, violence, or both increases the subsequent risks of experiencing housing insecurity or violence. Lagged housing insecurity is estimated to increase men's subsequent housing insecurity by 48 to 51 percentage points, and lagged violence is estimated to increase men's subsequent violence by about 22 percentage points. As with the descriptive results, lagged violence only increases the risks of housing insecurity among men who were previously housing secure, while lagged housing insecurity only increases the risks of violence among men who had not previously experienced violence.

The probit models also lead to smaller estimates of dynamic associations for women. However, unlike men, the models lead to a loss of statistical significance. For women, lagged housing insecurity either with or without violence is associated with significantly higher risks of housing insecurity, but the coefficient on the lagged condition of experiencing violence while being housing secure becomes statistically insignificant $(p=.140)$. Similarly, lagged violence with or without housing insecurity is estimated to raise women's subsequent risks of violence by significant amounts, but the coefficient on lagged housing insecurity without violence is only marginally significant $(p=.098)$.

\section{Bivariate Random-Effect Probit Models}

The probit models account for observed characteristics that are mutually correlated with early and later experiences of housing insecurity and violence. However, the estimated relationships between early and later experiences may still be confounded by correlations with unobserved characteristics. To address these issues, we respecified our models as bivariate, random-effect probit specifications. We assume that the error terms in our models can be decomposed into time-invariant random effects, $\eta_{i}$ and $\mu_{i}$, and time-varying idiosyncratic 
components, $\varepsilon_{i, t}$ and $v_{i, t}$, such that

$$
\varepsilon_{i, t}{ }^{*}=\eta_{i}+\varepsilon_{i, t} \quad \text { and } \quad v_{i, t}{ }^{*}=\mu_{i}+v_{i, t} .
$$

We assume that each unobserved term is normally distributed with mean zero and that the timeinvariant components are independent of the time-varying components. We further allow the two random effects to be correlated (correlation $\rho_{\eta \mu}$ ) and the two time-varying terms to be correlated (correlation, $\rho_{\varepsilon v}$ ). The inclusion of random effects addresses biases that arise from time-invariant unobserved characteristics that are correlated with the lags of the own outcomes in each model (lagged housing insecurity in the housing model and lagged violence in the violence model). Allowing for correlated random effects addresses biases in the cross-lagged associations.

To account for people's initial housing insecurity and violence status, we estimate the bivariate random-effect specifications jointly with probit models for people's status in wave 1

$$
\begin{aligned}
& H_{i, 1}{ }^{*}=\gamma_{X}{ }^{\prime} X_{i, 1}+\gamma_{Z}{ }^{\prime} Z_{i}+\lambda \eta_{i}+e_{i} \\
& V_{i, 1}{ }^{*}=\psi_{X}{ }^{\prime} X_{i, 1}+\psi_{Z} Z_{i}+\kappa \mu_{i}+u_{i}
\end{aligned}
$$

where the $\gamma$ and $\psi$ terms are vectors of coefficients, $\lambda$ and $\kappa$ are scalar coefficients (factor loadings), and $e_{i}$ and $u_{i}$ are error terms with a bivariate normal distribution (correlation $\rho_{e u}$ ) that are independent of $\eta_{i}$ and $\mu_{\mathrm{i}}$. We estimate the joint system of dynamic bivariate random-effect probit models and initial conditions models using Stata's Generalized Structural Equations Modelling (gsem) package, which uses maximum likelihood estimation to fit multi-equation systems of non-linear models, such as probits and logits, with linear latent variable specifications and shared random-effect errors. ${ }^{7}$

\footnotetext{
${ }^{7}$ Because of limitations in gsem, we account for the correlations between $\varepsilon_{i, t}$ and $v_{i, t}$ and between $e_{i}$ and $u_{i}$ through the following factor specifications:
} 
Table 4 reports estimation results from the dynamic bivariate random-effect probit models, (1), (2) and (3), from this full system (estimation results for the initial conditions models (4) and (5) are omitted but available upon request). The inclusion of correlated random effects further diminishes the estimated associations between the lagged and current housing insecurity and violence outcomes. For men, the coefficients for each of the lagged housing and violence conditions are statistically different from zero. Being housing insecure in one period is estimated to raise men's risks of subsequent housing insecurity by about 32 percentage points, while experiencing violence is estimated to raise men's risks of subsequent violence by 8 to 9 percentage points. Experiencing violence increases the risks of housing insecurity for men who are initially housing secure, and housing insecurity increases the risks of violence for men who did not initially experience violence. For women, lagged housing insecurity is positively associated with subsequent housing insecurity, and lagged violence is positively associated with subsequent violence. However, there are no significant cross-lagged associations.

The evidence of state dependence is consistent with several prior studies, including Allgood and Warren (2003) and Piliavan et al. (1996), but contrasts with the findings of CobbClark et al. (2016), who also examined the JH survey and accounted for random effects in the duration process. Cobb-Clark et al. estimated hazard models of housing insecurity spells but dropped spells that were on-going as of the first wave because they did not know how long those spells had progressed. Their exclusion dropped many spells, including a disproportionate number of long spells, which may have limited their ability to detect state dependence.

$$
\varepsilon_{i, t}=f_{i, t}+\zeta_{i, t} \quad v_{i, t}=\theta f_{i, t}+\omega_{i, t} \quad e_{i}=g_{i}+w_{i} \quad u_{i}=\tau g_{i}+r_{i}
$$

where $f_{i, t}, g_{i}, \zeta_{i, t}, \omega_{i, t}, w_{i}$, and $r_{i}$ are independently normally distributed random variables with variances normalized to be one and $\theta$ and $\tau$ are factor loading parameters that are estimated. 
Among the other observed characteristics in our models, the number of children reduces men's and women's risks of housing insecurity, while psychological distress and marijuana use increase the risks. Men's risks of housing insecurity are also reduced by employment, and women's risks of housing insecurity are higher if they experienced violence as an adult prior to the JH survey. Thus, violence may raise women's long-term risks of housing insecurity, even if it does not affect their near-term risks. Women's risks of housing insecurity fall with age through age 40 and if they have been diagnosed with a psychological condition.

A novel element of the JH survey is that it asked about sexual orientation. Previous research has found that sexual minorities are over-represented among homeless youth (see the review by Ecker 2016), but there has been almost no quantitative research for adults. As with the studies for youth, we find that lesbian and bisexual women face higher risks of housing insecurity than heterosexual women. However, we find no association between sexual orientation and housing insecurity for men; the null finding for men may be a result the high levels of overall disadvantage and early homelessness in the JH sample.

In the models for violence, heavy drinking and childhood abuse and neglect raise the risks of violence for men and women. For men, being a migrant, living in a small city, and having a psychological condition reduce the risks of violence, while poor health and marijuana use increase them. For women, poor health lowers the risks of violence, while being in couple, higher incomes, experiencing psychological distress, and having a psychological condition raise the risks.

Several of these findings are expected, including the deleterious effects of substance abuse, childhood abuse and neglect, and psychological distress. Other results are more surprising, especially psychological conditions and poor health reducing men's risks of housing 
insecurity and poor health reducing women's vulnerability to violence. Cobb-Clark et al. (2016) also found that some bad health outcomes reduced the duration of Australians' homelessness. The estimated associations might reflect these conditions leading to prioritized social services or a more consistent provision of services (e.g., fewer requirements on the receipt of services).

At the bottom of Table 4, we list estimated correlation coefficients for our controls for unobserved selection. The random effects in our specifications adjust for serial correlation in each model's unobserved determinants. Table 4 lists the implied longitudinal correlation coefficients within each model. All four specifications have substantial and statistically significant amounts of serial correlation, and accounting for these correlations reduces the estimated coefficients on the lags of the dependent variables (e.g., reduces the coefficients on lagged housing insecurity in the housing insecurity model). For women, there is a modest but imprecisely estimated positive correlation between the random effects in the housing insecurity and violence models. Allowing for this correlation leads to smaller estimated cross-lag effects for women. For men, there is little correlation between the random effects, and allowing for the correlation does not substantially alter their estimated cross-lag effects.

\section{$\underline{\text { Alternative Measures }}$}

As we discussed, the JH survey asked about other types of victimization. One question involved robberies and physical assaults that were reported to police. The incidence of these events was lower than for the physical violence measure with rates of 10 percent for men and 11 percent for women, suggesting that many violent events go unreported to the police. About onethird of respondents who reported robberies or assaults to police did not separately report experiencing physical violence. We created an alternative violence measure that took a value of one if a person indicated either experiencing violence or reporting a robbery or assault to the 
police; the incidence of this measure was 22.3 percent for men and 18.7 percent for women. We then re-estimated our bivariate, random-effects models using the revised violence indicator. Coefficients and marginal effects of the lagged housing insecurity and violence measures are reported in the top panel of Table 5. The estimates for the housing security models for men and women are very similar to those from the original specification. The estimates for the violence model are mostly similar to the original model, though there is stronger evidence that housing insecurity contributes to violence among people who had previously experienced violence.

The JH survey also asked about sexual assault in the six months preceding the interviews. The low incidence of sexual assault precludes a direct multivariate analysis of this outcome. However, as a sensitivity test we respecified the violence measure to include experiencing either physical violence or sexual assault and re-estimated our bivariate, random-effects models. About half of men and 40 percent of women who reported sexual assaults did not separately report physical violence, but because of the low incidence of sexual assault, the incidence of the composite measure was only slightly higher than the incidence for physical violence. The estimated associations for men are nearly identical to those from the original specification, while the estimated associations for women are marginally weaker.

As an alternative to our measure of housing insecurity, we also considered a measure of literal homelessness. Only 11 percent of $\mathrm{JH}$ men and seven percent of $\mathrm{JH}$ women reported being literally homeless in the months leading up to their interviews. We re-estimated the bivariate random-effects probit model for men using the literal homelessness measure and report estimates in the middle left panel of Table 5. The estimates continue to provide evidence of state dependence, with literal homelessness in one period increasing the risks of homelessness in the next and violence in one period increasing the risks of violence in the next. However, there is no 
significant evidence of cross-lag effects for men when the literal homelessness measure is used.

Because of the low incidence of literal homelessness among women, we were not able to re-estimate random-effects models for them but were able to estimate standard probit models, similar to those listed in Table 3. Results from these models are reported in the middle right panel of Table 5. The estimates show strong associations in the lagged own outcome variables that are consistent with state dependence. However, unlike the bivariate, random-effects probit estimates for men and the earlier probit estimates of housing insecurity for women, the probit models of women's literal homelessness also show a strong association between earlier violence and later homelessness. The associations are somewhat tentative because they do not control for selection from unobservable characteristics.

To examine the sensitivity of our estimates to the choice of including one period lags for housing insecurity and violence, we respecify the bivariate, random-effects models to include two period lags for housing insecurity and violence. The results from these models are reported in the bottom panel of Table 5. The estimates continue to provide estimates of state dependence for men in housing insecurity and violence. However, we no longer find statistically significant cross-state dependence of prior period housing insecurity, one or two periods, with subsequent violence for men among men who did not previously experience violence. For women, the new specification produces estimates similar to prior results — evidence of state dependence but not cross-state dependence for a one period lag. However, the two period lag for violence while housing secure is estimated to raise women's risk of subsequent housing insecurity by nine percentage points.

\section{CONCLUSIONS AND DISCUSSION}

In this paper we have used data from the Journeys Home survey to investigate how 
disadvantaged Australians' experiences with violence and housing insecurity over a series of (approximately) six-month periods affect their experiences with violence and housing insecurity in the subsequent six-month periods. Our study is one of only a few to examine these outcomes prospectively. It is also distinctive in examining outcomes for women and men and in disaggregating its analyses by gender. We estimate dynamic bivariate probit models that incorporate direct controls for many observed characteristics and correlated random effects controls for time-invariant unobserved characteristics to mitigate effects from these potential sources of bias.

Disadvantaged women's and men's experiences with violence and housing insecurity differ markedly. Policy prescriptions emphasise intimate partner violence as a prime cause of women's homelessness. Consistent with that concern, we find that one-in-seven JH women experiences physical violence in a given six-month period, that intimate partners perpetrate most of that violence, and that women are much more likely than men to report being harmed or experiencing anxiety as a result of violence.

As grim as those statistics are, JH men's chances of experiencing violence are 29 percent higher than JH women's. Men also experience more housing insecurity, including more time in primary homelessness, literal homelessness and culturally inappropriate accommodations than women. Clearly, violence and housing insecurity are substantial problems for disadvantaged women and men.

Our multivariate analyses further demonstrate that violence and housing insecurity in one period greatly increase the risks of these problems happening again. The point estimates for men indicate that lagged housing insecurity raises the probability of subsequent housing insecurity by about 32 percentage points and doubles the risk in relative terms. Women's lagged housing 
insecurity raises their subsequent chances of housing insecurity by 19 to 22 percentage points.

The point estimates for men indicate that lagged violence raises subsequent violence by eight to nine percentage points, while point estimates for women indicate an effect of seven to 11 percentage points. Similar findings appear in other models with alternative definitions of housing insecurity and violence. The results for housing insecurity are consistent with housing problems creating barriers to subsequent secure housing, possibly through losses of productivity or acculturation into homelessness. The results for violence are consistent with stress-related theories regarding vulnerabilities for re-victimization.

Our findings regarding cross-lag effects are more intriguing. Our unconditional analyses show that violence is strongly positively correlated with subsequent housing insecurity for disadvantaged men and women and, vice versa, that housing insecurity is positively correlated with subsequent violence. Although some of the evidence for men is new, the findings for women corroborate results from other descriptive studies. The estimated associations are weaker, however, in our multivariate models. For men the models indicate that violence is associated with subsequent housing insecurity but only among those who were previously housing secure. The models also indicate that housing insecurity contributes to subsequent violence for men but only among those who had not initially experienced violence. At the same time, the models, especially those that control for selection on unobserved characteristics, provide little evidence of violence affecting women's subsequent near-term housing insecurity or of housing problems affecting subsequent violence. The lack of associations for women has precedent; Brown and Bassuk (1997), Lehmann et al. (2007) and Shelton et al. (2009) also failed to detect linkages between violence and subsequent homelessness. However, we do find longer-term associations between violence and subsequent housing insecurity when we use a two-period lag for violence 
and a control for ever experiencing violence prior to the JH survey.

The gender differences in the cross-lagged near-term associations could be consistent with the greater availability of family and homeless services for women and the prioritization of services for women confronting domestic violence. This explanation has some weaknesses, however, as the services do not seem to break the links between JH women's earlier and later violence or their earlier and later housing problems. Another explanation may rest with gender differences in the causes of violence. The JH survey asks whether people experienced violence but not whether they were victimized by violence. Men may be more likely to instigate violence than women, and some of the violence that men report could be the result of fights or other mutually violent episodes. Differences in instigation could explain men's lower rates of reporting fear and anxiety after experiencing violence. It is possible that victimization does not contribute much to housing insecurity but that a proclivity to instigate or engage in fights does.

In addition to the results regarding lagged outcomes, we find that psychological distress and cannabis use increase the risks of housing insecurity for disadvantaged men and women and that the number of children and diagnoses of psychological conditions reduce the risks. Although children and psychological problems would seem to increase people's vulnerabilities, they might also result in prioritized access to housing services. There are also differences in women's and men's housing risks. Women who are bisexual or lesbians are more likely to be housing insecure, but bisexual and gay men are not.

For men and women, heavy drinking and childhood abuse are each significant predictors of violence. Marijuana use and poor health raise men's risks of violence, while diagnoses of psychological conditions reduce them. However, marijuana use is an insignificant predictor of women's violence, while poor health is estimated to lower the risks and psychological conditions 
are estimated to raise them. The models also indicate that $\mathrm{JH}$ women with higher incomes and women who are married or in de facto relationships face higher chances of violence.

Researchers are increasingly emphasizing bad-luck shocks as a precipitating cause of homelessness among vulnerable people. Violence has properties of a shock; it has a low probability of occurring, even among people with multiple risk factors. We examined distribution of predictions from our random-effects model of violence and found only 2.6 percent of the observations for men and 1.7 percent of the observations for women had more than a 50/50 chance of experiencing violence. In this light, the results from our multivariate specifications provide some support for the shock hypothesis, though mainly for disadvantaged men. However, a shock interpretation is called into question if men are instigating the violence that is causing their housing insecurity.

There are some qualifications regarding our results. The chief qualification is that the JH survey is representative of an especially disadvantaged set of initial public assistance clients who were at risk of housing insecurity. This is a relevant population to study, but it is more disadvantaged than public assistance clients generally and obviously not representative of the overall Australian population. Differences in the populations can be seen in the relatively high rates of violence reported by the $\mathrm{JH}$ respondents as well as in the high rates of health, psychological, and substance abuse problems and low rates of employment. Combinations of violence and housing insecurity outcomes predict subsequent changes in these outcomes among our vulnerable sample; however, the associations may differ for Australians with more resources.

The high rates of intimate partner violence among women and our finding that violence in one period increases women's risks of subsequent violence show the need for programs and campaigns to reduce women's violence. However, our findings should also prompt housing 
advocates and public officials to carefully consider the importance of men's violence. Although women's victimization is the target of special coordinated programs, men's victimization is not. Our results show that violence is a substantial risk factor for men's housing problems. Initiatives to improve disadvantaged men's safety and to reduce their violence could be tools in lowering their high rates of housing insecurity. 


\section{REFERENCES}

Allgood, S., and R. Warren Jr. "The Duration of Homelessness: Evidence From a National Survey.” Journal of Housing Economics, 12(4), 2003, 273-90.

Australian Bureau of Statistics. Census of Population and Housing: Estimating Homelessness 2011. Canberra: Australian Bureau of Statistics, 2012.

Australian Institute of Health and Welfare. Specialist Homelessness Services 2011-12. Canberra: AIHW, 2012.

Bandura, A. Self-Efficacy: The Exercise of Control. New York: W.H. Freeman, 1997.

Basile, K., I. Arias, S. Desai, and M. Thompson. “The Differential Association of Intimate Partner Physical, Sexual, Psychological, and Stalking Violence and Posttraumatic Stress Symptoms in a Nationally Representative Sample of Women." Journal of Traumatic Stress, $17(5), 2004,413-21$.

Bassuk, E., J. Buckner, L. Weinreb, A. Browne, S. Bassuk, R. Dawson, and J. Perloff. "Homelessness in Female-Headed Families: Childhood and Adult Risk and Protective Factors." American Journal of Public Health, 87(2), 1997, 241-8.

Bassuk, E., J. Perloff, and R. Dawson. "Multiply Homeless Families: The Insidious Impact of Violence.” Housing Policy Debate, 12(2), 2001, 299-320.

Bevitt, A., A. Chigavazira, R. Scutella, Y. Tseng, and N. Watson. Journeys Home User Manual: User Manual Version: 6.0.2. Melbourne: Melbourne Institute of Applied Economic and Social Research, 2014.

Breiding, M., S. Smith, K. Basile, M. Walters, J. Chen, and M. Merrick. "Prevalence and Characteristics of Sexual Violence, Stalking, and Intimate Partner Violence Victimization National Intimate Partner and Sexual Violence Survey, United States, 2011.” Morbidity and 
Mortality Weekly Report, 63(8), 2014.

Burt, M. "Causes of the Growth of Homelessness During the 1980s." Housing Policy Debate, 2(3), 1991, 901-36.

Burt, M., L. Aron, E. Lee, and J. Valente. Helping America's Homeless: Emergency Shelter or Affordable Housing? Washington D.C.: The Urban Institute Press, 2001.

Caton, C., B. Dominguez, B. Schanzer, D. Hasin, P. Shrout, A. Felix, H. McQuistion, L. Opler, and E. Hsu. "Risk Factors for Long-Term Homelessness: Findings From a Longitudinal Study of First-Time Homeless Single Adults.” American Journal of Public Health, 95(10), 2005, 1753-9. Chamberlain, C., and G. Johnson. "How Many Australians Have Slept Rough?” Australian Journal of Social Issues, 50(4), 2015, 439-57.

Chu, J. "The Revictimization of Adult Women with Histories of Childhood Abuse." The Journal of Psychotherapy Practice and Research, 1(3), 1992, 259-69.

Cobb-Clark, D., N. Herault, R. Scutella, and Y. Tseng. “A Journey Home: What Drives How Long People Are Homeless?” Journal of Urban Economics, 91, 2016, 57-72.

Commonwealth of Australia. The Road Home: A National Approach to Reducing Homelessness. Canberra: Department of Families, Housing, Community Services and Indigenous Affairs, 2008. Curtis, M., H. Corman, K. Noonan, and N. Reichman. "Life Shocks and Homelessness." Demography, 50(6), 2013, 2227-53.

Dennis, D., I. Levine, and F. Osher. "The Physical and Mental Health Status of Homeless Adults." Housing Policy Debate, 2(3), 1991, 815-35.

Early, D. “An Empirical Investigation of the Determinants of Street Homelessness." Journal of Housing Economics, 14(1), 2005, 27-47.

Ecker, J. 2016. "Queer, Young, and Homeless: A Review of the Literature." Child \& Youth 
Services, 37(4), 2016, 325-61.

Fischer, P. "Victimization and Homelessness: Cause and Effect." New England Journal of Public Policy, 8(1), 1992, 229-46.

Flinders Institute for Housing, Urban and Regional Research. Women, Domestic and Family

Violence and Homelessness: A Synthesis Report. Report prepared for the Department of

Families, Housing, Community Services and Indigenous Affairs, Canberra, 2008.

Frias, S., and Ronald A. "Stability and Change in the Experience of Partner Violence Among Low-Income Women.” Social Science Quarterly, 88(5), 2007, 1281-306.

Garland, T., T. Richards, and M. Cooney. "Victims Hidden in Plain Sight: The Reality of Victimization among the Homeless.” Criminal Justice Studies, 23(4), 2010, 285-301.

Gecas, V. “The Social Psychology of Self-Efficacy.” Annual Review of Sociology, 15, 1989, 291-316.

Geissler, L., C. Bormann, C. Kwiatkowski, G. N. Braucht, and C. Reichardt. "Women, Homelessness, and Substance Abuse: Moving Beyond the Stereotypes." Psychology of Women Quarterly, 19(1), 1995, 65-83.

Geller, A., and A. Franklin. "Paternal Incarceration and the Housing Security of Urban Mothers." Journal of Marriage and the Family, 76(2), 2014, 411-27.

Gidycz, C., K. Hanson, and M. Layman. "A Prospective Analysis of the Relationships Among Sexual Assault Experiences." Psychology of Women Quarterly, 19, 1995, 5-29.

Glomm, G., and A. John. "Homelessness and Labor Markets." Regional Science and Urban Economics, 32(5), 2002, 591-606.

Gould, T., and A. Williams. "Family Homelessness: An Investigation of Structural Effects." Journal of Human Behavior in the Social Environment, 20(2), 2010, 170-90. 
Herman, D., E. Susser, E. Struening, and B. Link. "Adverse Childhood Experiences: Are They

Risk Factors for Adult Homelessness.” American Journal of Public Health, 87(2), 1997, 249-55.

Hindelang, M., M. Gottfredson, and J. Garofalo. Victims of Personal Crime: An Empirical

Foundation for a Theory of Personal Victimization. Cambridge: Ballinger Publishing Company, 1978.

Hodgson, K., K. Shelton, M. van den Bree, and F. Los. "Psychopathology in Young People Experiencing Homelessness: A Systematic Review." American Journal of Public Health, 103(6), 2013, e1-e14.

Hotaling, G. and D. Sugarman. “A Risk Marker Analysis of Assaulted Wives.” Journal of Family Violence, 5(1), 1990, 1-13.

Jasinski, J., J. Wesely, E. Mustaine, and J. Wright. The Experience of Violence in the Lives of Homeless Women: A Research Report. Document No. 211976. Washington, DC: U.S.

Department of Justice, 2005.

Jencks, C. The Homeless. Cambridge: Harvard University Press, 1994

Johnson, G., D. Ribar, and A. Zhu. “Women’s Homelessness: International Evidence on Causes, Consequences, Coping and Policies," in Oxford Handbook on the Economics of Women, edited by S. Averett, L. Argys, and S. Hoffman. New York: Oxford University Press, forthcoming. Kipke M., T. Simon, S. Montgomery, J. Unger, and E. Iversen. "Homeless Youth and Their Exposure to and Involvement in Violence While Living on the Streets.” Journal of Adolescent Health, 20(5), 1997, 360-7.

Koegel, P., E. Melamid, and M. A. Burnam. "Childhood Risk Factors for Homelessness among Homeless Adults.” American Journal of Public Health, 85(12), 1995, 1642-9. 
Lam, J., and R. Rosenheck. "The Effect of Victimization on Clinical Outcomes of Homeless Persons with Serious Mental Illness.” Psychiatric Services, 49(5), 1998, 678-83.

Lauritsen, J., and K. D. Quinet. "Repeat Victimization Among Adolescents and Young Adults." Journal of Quantitative Criminology, 11(2), 1995, 143-66.

Lee, B., and C. Schreck. "Danger on the Streets: Marginality and Victimization Among Homeless People.” American Behavioral Scientist, 48(8), 2005, 1055-81.

Lehmann, E., P. Kass, C. Drake, and S. Nichols. "Risk Factors for First-Time Homelessness in Low-Income Women.” Journal of Orthopsychiatry, 77(1), 2007, 20-8.

McEwen, B. "Stress, Adaptation, and Disease: Allostasis and Allostatic Load." Annals of the New York Academy of Sciences, 840, 1998, 33-44.

McVicar, D., J. Moschion, and J. van Ours. "From Substance Use to Homelessness or Vice Versa.” Social Science \& Medicine 136-137, 2015, 89-98.

O’Flaherty, B. "Wrong Person and Wrong Place: For Homelessness, the Conjunction is What Matters." Journal of Housing Economics, 13(1), 2004, 1-15.

_ . "What Shocks Precipitate Homelessness?" Unpublished manuscript. New York: Columbia University, 2009.

—_. "Homelessness as Bad Luck: Implications for Research and Policy," in How to House the Homeless, edited by I. Gould and B. O'Flaherty. New York: Russell Sage Foundation, 2010, $143-82$.

Piliavin, I., B. E. Wright, R. Mare, and A. Westerfelt. "Exits and Returns to Homelessness." Social Service Review, 70(1), 1996, 33-57.

Quigley, J., and S. Raphael. "The Economics of Homelessness: The Evidence from North America." European Journal of Housing Policy, 1(3), 2001, 323-36. 
Quigley, J., S. Raphael, and E. Smolensky. "Homeless in America, Homeless in California." The Review of Economics and Statistics, 83(1), 2001, 37-51.

Ribar, D. "Early Research Findings from Journeys Home: Longitudinal Study of Factors Affecting Housing Stability.” Australian Economic Review, 50(3), 2017, 214-9.

Ruback, R. B., V. Clark, and C. Warner. "Why Are Crime Victims at Risk of Being Victimized Again? Substance Use, Depression, and Offending as Mediators of the VictimizationRevictimization Link.” Journal of Interpersonal Violence, 29(1), 2014, 157-85.

Shelton, K., P. Taylor, A. Bonner, and M. van den Bree. "Risk Factors for Homelessness:

Evidence from a Population-Based Study.” Psychiatric Services, 60(4), 2009, 465-72.

Shinn, M., J. Baumohl, and K. Hopper. "The Prevention of Homelessness Revisited.” Analyses of Social Issues and Public Policy, 1(1), 2001, 95-127.

Shinn, M., B. Weitzman, D. Stojanovic, J. Knickman, L. Jimenez, L. Duchon, S. James, and D. Krantz. "Predictors of Homelessness Among Shelter Families in New York City: From Shelter Request to Housing Stability.” American Journal of Public Health, 88(11), 1998, 1651-7.

Snow, D., and L. Anderson. "Identity Work Among the Homeless: The Verbal Construction and Avowal of Personal Identities." The American Journal of Sociology, 92(6), 1987, 1336-71.

Tauchen, H., and A. D. Witte. “The Dynamics of Domestic Violence.” The American Economic Review, 85(2), 1995, 414-18.

Truman, J., and L. Langton. Criminal Victimization, 2014. Bulletin NCJ 248973. Washington, DC: Bureau of Justice Statistics, 2015.

U.S. Department of Housing and Urban Development. 2015 Annual Homeless Assessment Report (AHAR) to Congress. Part 1: Point-in-Time Estimates of Homelessness. Washington: HUD, 2016. 
U.S. Interagency Council on Homelessness. Opening Doors: Federal Strategic Plan to Prevent and End Homelessness. Washington, DC: U.S. Interagency Council on Homelessness, 2015. Weitzman, B., J. Knickman, and M. Shinn. "Pathways to Homelessness Among New York City Families.” Journal of Social Issues, 46(4), 1990, 125-40.

Wenzel, S., B. Leake, and L. Gelberg. "Risk Factors for Major Violence Among Homeless Women." Journal of Interpersonal Violence, 16(8), 2001,739-52.

Williams, S., and K. Mickelson. "The Nexus of Domestic Violence and Poverty." Violence Against Women, 10(3), 2004, 283-93.

Wooden, M., A. Bevitt, A. Chigavazira, N. Greer, G. Johnson, E. Killackey, J. Moschion, R. Scutella, Y. Tseng, and N. Watson. "Introducing 'Journeys Home." Australian Economic Review, 45(3), 2012, 368-78. 
TABLE 1

Characteristics of Violence and Housing Insecurity

Panel A: Characteristics of violence conditional on gender and housing insecurity

\begin{tabular}{|c|c|c|c|c|c|c|}
\hline \multirow[b]{2}{*}{ Characteristic } & \multicolumn{3}{|c|}{ Men } & \multicolumn{3}{|c|}{ Women } \\
\hline & $\begin{array}{l}\text { All } \\
(1) \\
\end{array}$ & $\begin{array}{c}\text { H. secure } \\
(2)\end{array}$ & $\begin{array}{c}\text { H. insecure } \\
\text { (3) }\end{array}$ & $\begin{array}{l}\text { All } \\
(4) \\
\end{array}$ & $\begin{array}{c}\text { H. secure } \\
(5)\end{array}$ & $\begin{array}{c}\text { H. insecure } \\
(6)\end{array}$ \\
\hline \multicolumn{7}{|l|}{ Among entire analysis sample } \\
\hline Violence in last 6 months $(\%)$ & 18.8 & 14.6 & $24.2 * * *$ & $14.6 * * *$ & 11.4 & $21.5 * * *$ \\
\hline Sexual assault in last 6 mo. $(\%)$ & 0.9 & 0.8 & 1.1 & $2.8 * * *$ & 1.8 & $4.9 * * *$ \\
\hline Person-wave observations $(N)$ & 3209 & 1778 & 1431 & 2525 & 1730 & 795 \\
\hline \multicolumn{7}{|c|}{ Among those who reported violence in last 6 months } \\
\hline Harmed $(\%)$ & 58.4 & 56.0 & 60.1 & $75.5 * * *$ & 69.0 & $82.9 * * *$ \\
\hline Experienced anxiety, fear (\%) & 33.2 & 28.2 & $36.9 * *$ & $69.2 * * *$ & 65.7 & 73.4 \\
\hline Experienced multiple events $(\%)$ & 10.3 & 6.9 & $14.4^{* * *}$ & $8.7 * *$ & 5.8 & $14.9 * * *$ \\
\hline Relationship to assailant $^{\mathrm{a}}$ & & & & $/ * * *$ & & $/ * *$ \\
\hline Stranger $(\%)$ & 44.8 & 50.4 & 40.7 & 12.8 & 13.3 & 12.3 \\
\hline Non-cores. rom. partner (\%) & 4.0 & 5.1 & 3.2 & 20.7 & 20.9 & 20.5 \\
\hline Co-res. partner at interview (\%) & 1.8 & 1.6 & 2.0 & 5.4 & 6.1 & 4.7 \\
\hline Co-res. partner before int. (\%) & 3.3 & 2.3 & 4.1 & 13.1 & 7.7 & 19.3 \\
\hline Former co-res. partner $(\%)$ & 1.8 & 1.6 & 2.0 & 17.7 & 17.9 & 17.5 \\
\hline Other known person $(\%)$ & 44.2 & 39.1 & 48.0 & 30.2 & 34.2 & 25.7 \\
\hline Person-wave observations $(N)$ & 605 & 259 & 346 & 369 & 198 & 171 \\
\hline
\end{tabular}

Panel B. Characteristics of housing insecurity conditional on gender and violence

\begin{tabular}{|c|c|c|c|c|c|c|}
\hline \multirow[b]{2}{*}{ Characteristic } & \multicolumn{3}{|c|}{ Men } & \multicolumn{3}{|c|}{ Women } \\
\hline & All & No vio. & Violence & All & No vio. & Violence \\
\hline \multicolumn{7}{|l|}{ Among entire analysis sample } \\
\hline Housing insecure $(\%)$ & 44.6 & 41.7 & $57.2 * * *$ & $31.5 * * *$ & 28.9 & $46.3 * * *$ \\
\hline Person-wave observations $(N)$ & 3209 & 2604 & 605 & 2525 & 2156 & 369 \\
\hline \multicolumn{7}{|c|}{ Among those who were housing insecure } \\
\hline Time housed in own place $(\%)$ & 22.0 & 21.2 & 24.5 & $33.3 * * *$ & 32.6 & 36.0 \\
\hline Time in house or unit $(\%)$ & 51.3 & 50.1 & $55.1 *$ & $70.2 * * *$ & 69.6 & 72.5 \\
\hline Time primary homeless $(\%)$ & 7.0 & 6.4 & $8.8^{*}$ & $3.8 * * *$ & 3.6 & 4.5 \\
\hline Time in tert. homelessness (\%) & 37.9 & 40.1 & $30.8 * * *$ & $24.9 * * *$ & 26.0 & 21.0 \\
\hline Person-wave observations $(N)$ & 1431 & 1085 & 346 & 795 & 624 & 171 \\
\hline
\end{tabular}

Note: The tables report statistics for respondents reporting each characteristic that were calculated using unweighted longitudinal data from the JH survey. Asterisks indicate statistically significant differences in the characteristic by either gender (column (4)) or housing insecurity or violence status (columns (3) and (6)) based on $\chi^{2}$ and $t$ tests.

${ }^{a}$ Asterisks indicate results from $\chi^{2}$ tests of differences in the relationship distribution.

* Significant at 0.1 level. $\quad * *$ Significant at 0.05 level $\quad * * *$ Significant at 0.01 level. 
TABLE 2

Current Housing and Violence Outcomes Conditional on Previous Outcomes

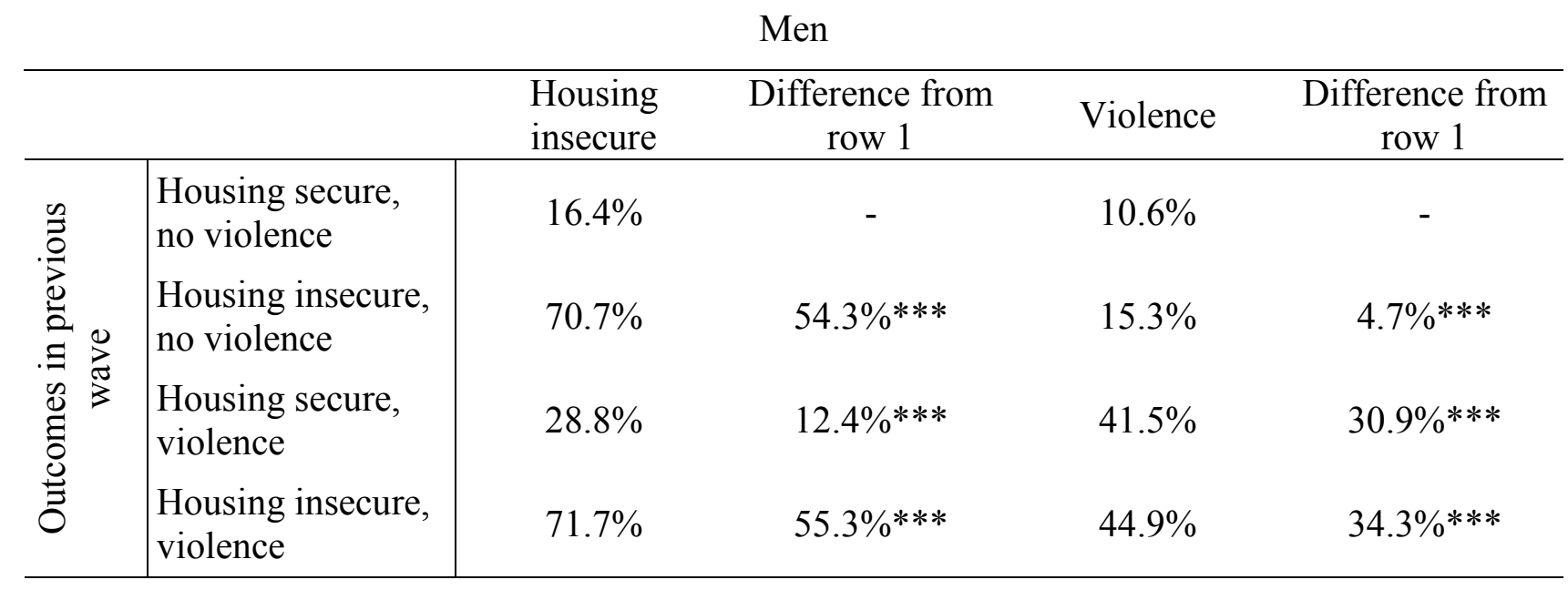

\begin{tabular}{|c|c|c|c|c|c|}
\hline \multicolumn{6}{|c|}{ Women } \\
\hline & & $\begin{array}{l}\text { Housing } \\
\text { insecure }\end{array}$ & $\begin{array}{c}\text { Difference from } \\
\text { row } 1\end{array}$ & Violence & $\begin{array}{c}\text { Difference from } \\
\text { row } 1\end{array}$ \\
\hline \multirow{4}{*}{ 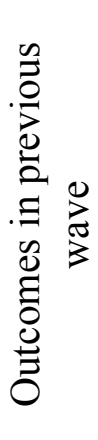 } & $\begin{array}{l}\text { Housing secure, } \\
\text { no violence }\end{array}$ & $14.2 \%$ & - & $8.8 \%$ & - \\
\hline & $\begin{array}{l}\text { Housing insecure, } \\
\text { no violence }\end{array}$ & $53.2 \%$ & $39.0 \% * * *$ & $12.4 \%$ & $3.7 \% * *$ \\
\hline & $\begin{array}{l}\text { Housing secure, } \\
\text { violence }\end{array}$ & $20.1 \%$ & $5.9 \% *$ & $31.4 \%$ & $22.7 \% * * *$ \\
\hline & $\begin{array}{l}\text { Housing insecure, } \\
\text { violence }\end{array}$ & $60.9 \%$ & $46.6 \% * * *$ & $40.6 \%$ & $31.8 \% * * *$ \\
\hline
\end{tabular}

Note: The tables show percentages of people experiencing housing insecurity and violence conditional on their previous experiences with the listed outcomes using unweighted longitudinal data from the JH survey.

* Significant at 0.1 level. $\quad * *$ Significant at 0.05 level $\quad * * *$ Significant at 0.01 level. 
TABLE 3

Housing Insecurity and Violence Probit Model Results

\begin{tabular}{|c|c|c|c|c|}
\hline & \multicolumn{2}{|c|}{ Men } & \multicolumn{2}{|c|}{ Women } \\
\hline & $\begin{array}{c}\text { Housing } \\
\text { insecurity }\end{array}$ & Violence & $\begin{array}{c}\text { Housing } \\
\text { insecurity }\end{array}$ & Violence \\
\hline \multicolumn{5}{|l|}{ Lagged outcome measures } \\
\hline $\begin{array}{l}\text { Housing insecure, no } \\
\text { violence } t-1\end{array}$ & $\begin{array}{c}1.456^{* * *} \\
(0.066) \\
0.507\end{array}$ & $\begin{array}{c}0.181 * * \\
(0.077) \\
0.037\end{array}$ & $\begin{array}{c}1.045^{* * *} \\
(0.075) \\
0.339\end{array}$ & $\begin{array}{c}0.165^{*} \\
(0.098) \\
0.028\end{array}$ \\
\hline $\begin{array}{l}\text { Housing secure, violence } \\
t-1\end{array}$ & $\begin{array}{c}0.333^{* * *} \\
(0.107) \\
0.097\end{array}$ & $\begin{array}{c}0.834 * * * \\
(0.106) \\
0.224\end{array}$ & $\begin{array}{c}0.190 \\
(0.129) \\
0.047\end{array}$ & $\begin{array}{c}0.621 * * * \\
(0.125) \\
0.134\end{array}$ \\
\hline $\begin{array}{l}\text { Housing insecure, violence } \\
t-1\end{array}$ & $\begin{array}{c}1.391^{* * *} \\
(0.100) \\
0.485\end{array}$ & $\begin{array}{c}0.821^{* * *} \\
(0.100) \\
0.220\end{array}$ & $\begin{array}{l}1.176^{* * *} \\
(0.126) \\
0.389\end{array}$ & $\begin{array}{c}0.872^{* * *} \\
(0.131) \\
0.209\end{array}$ \\
\hline \multicolumn{5}{|l|}{ Other explanatory variables } \\
\hline $\begin{array}{l}\text { Aboriginal or Torres Strait } \\
\text { Islander }\end{array}$ & $\begin{array}{l}-0.075 \\
(0.089)\end{array}$ & $\begin{array}{l}-0.027 \\
(0.099)\end{array}$ & $\begin{array}{c}0.094 \\
(0.098)\end{array}$ & $\begin{array}{c}0.074 \\
(0.113)\end{array}$ \\
\hline $\begin{array}{l}\text { Migrated from non-English } \\
\text { country }\end{array}$ & $\begin{array}{l}-0.043 \\
(0.132)\end{array}$ & $\begin{array}{l}-0.499^{* *} \\
(0.199)\end{array}$ & $\begin{array}{l}-0.129 \\
(0.135)\end{array}$ & $\begin{array}{l}-0.025 \\
(0.166)\end{array}$ \\
\hline Bisexual, gay, or lesbian & $\begin{array}{l}-0.070 \\
(0.132)\end{array}$ & $\begin{array}{l}-0.214 \\
(0.157)\end{array}$ & $\begin{array}{l}0.295^{* * *} \\
(0.110)\end{array}$ & $\begin{array}{l}-0.070 \\
(0.129)\end{array}$ \\
\hline Non-intact family at age 14 & $\begin{array}{l}-0.009 \\
(0.064)\end{array}$ & $\begin{array}{c}0.004 \\
(0.070)\end{array}$ & $\begin{array}{l}-0.076 \\
(0.075)\end{array}$ & $\begin{array}{c}0.028 \\
(0.087)\end{array}$ \\
\hline $\begin{array}{l}\text { In foster or institutional } \\
\text { care as child }\end{array}$ & $\begin{array}{c}0.086 \\
(0.074)\end{array}$ & $\begin{array}{l}-0.111 \\
(0.082)\end{array}$ & $\begin{array}{l}-0.092 \\
(0.088)\end{array}$ & $\begin{array}{l}-0.151 \\
(0.103)\end{array}$ \\
\hline $\begin{array}{l}\text { Childhood abuse and } \\
\text { neglect score }\end{array}$ & $\begin{array}{c}0.038 \\
(0.031)\end{array}$ & $\begin{array}{l}0.170^{* * *} \\
(0.034)\end{array}$ & $\begin{array}{l}-0.055 \\
(0.034)\end{array}$ & $\begin{array}{l}0.161^{* * *} \\
(0.038)\end{array}$ \\
\hline Homeless as child & $\begin{array}{l}-0.058 \\
(0.072)\end{array}$ & $\begin{array}{c}0.013 \\
(0.078)\end{array}$ & $\begin{array}{c}0.140 \\
(0.089)\end{array}$ & $\begin{array}{l}-0.040 \\
(0.102)\end{array}$ \\
\hline $\begin{array}{l}\text { Homeless before } J H \\
\text { survey }\end{array}$ & $\begin{array}{c}0.112 \\
(0.140)\end{array}$ & $\begin{array}{c}0.121 \\
(0.157)\end{array}$ & $\begin{array}{c}0.063 \\
(0.144)\end{array}$ & $\begin{array}{c}0.172 \\
(0.217)\end{array}$ \\
\hline $\begin{array}{l}\text { Experienced violence before } \\
J H \text { survey }\end{array}$ & $\begin{array}{l}-0.045 \\
(0.068)\end{array}$ & $\begin{array}{c}0.022 \\
(0.078)\end{array}$ & $\begin{array}{l}0.216^{* *} \\
(0.087)\end{array}$ & $\begin{array}{c}0.097 \\
(0.105)\end{array}$ \\
\hline $\begin{array}{l}\text { Incarcerated before } J H \\
\text { survey }\end{array}$ & $\begin{array}{l}-0.008 \\
(0.066)\end{array}$ & $\begin{array}{l}-0.030 \\
(0.074)\end{array}$ & $\begin{array}{l}-0.130 \\
(0.112)\end{array}$ & $\begin{array}{c}0.049 \\
(0.118)\end{array}$ \\
\hline Age & $\begin{array}{l}-0.017 \\
(0.016)\end{array}$ & $\begin{array}{l}-0.026 \\
(0.019)\end{array}$ & $\begin{array}{l}-0.064 * * * \\
(0.020)\end{array}$ & $\begin{array}{l}-0.012 \\
(0.025)\end{array}$ \\
\hline $\mathrm{Age}^{2} / 100$ & $\begin{array}{c}0.023 \\
(0.020)\end{array}$ & $\begin{array}{c}0.017 \\
(0.024)\end{array}$ & $\begin{array}{l}0.079 * * * \\
(0.026)\end{array}$ & $\begin{array}{c}0.011 \\
(0.032)\end{array}$ \\
\hline 10-11 years of schooling & $\begin{array}{l}0.161^{*} \\
(0.093)\end{array}$ & $\begin{array}{l}-0.140 \\
(0.103)\end{array}$ & $\begin{array}{l}-0.039 \\
(0.109)\end{array}$ & $\begin{array}{c}0.100 \\
(0.125)\end{array}$ \\
\hline $12+$ years of schooling & $\begin{array}{c}0.116 \\
(0.092)\end{array}$ & $\begin{array}{l}-0.013 \\
(0.101)\end{array}$ & $\begin{array}{l}-0.054 \\
(0.108)\end{array}$ & $\begin{array}{c}0.107 \\
(0.123)\end{array}$ \\
\hline
\end{tabular}




\begin{tabular}{|c|c|c|c|c|}
\hline College degree & $\begin{array}{c}0.034 \\
(0.178)\end{array}$ & $\begin{array}{l}-0.187 \\
(0.214)\end{array}$ & $\begin{array}{l}-0.004 \\
(0.200)\end{array}$ & $\begin{array}{c}0.152 \\
(0.220)\end{array}$ \\
\hline Small city $t-1$ & $\begin{array}{c}0.094 \\
(0.097)\end{array}$ & $\begin{array}{l}-0.227 * * \\
(0.111)\end{array}$ & $\begin{array}{c}0.177 \\
(0.112)\end{array}$ & $\begin{array}{c}0.051 \\
(0.138)\end{array}$ \\
\hline Rural area $t-1$ & $\begin{array}{l}-0.140 \\
(0.149)\end{array}$ & $\begin{array}{l}-0.066 \\
(0.162)\end{array}$ & $\begin{array}{c}0.184 \\
(0.165)\end{array}$ & $\begin{array}{l}(0.150) \\
-0.004 \\
(0.206)\end{array}$ \\
\hline In area rental price & $\begin{array}{c}0.195 \\
(0.171)\end{array}$ & $\begin{array}{l}-0.054 \\
(0.193)\end{array}$ & $\begin{array}{c}0.307 \\
(0.223)\end{array}$ & $\begin{array}{c}0.360 \\
(0.264)\end{array}$ \\
\hline Unemployment rate & $\begin{array}{l}-0.025 \\
(0.023)\end{array}$ & $\begin{array}{l}-0.018 \\
(0.026)\end{array}$ & $\begin{array}{r}0.050^{*} \\
(0.027)\end{array}$ & $\begin{array}{c}0.007 \\
(0.033)\end{array}$ \\
\hline Couple $t-1$ & $\begin{array}{l}-0.008 \\
(0.084)\end{array}$ & $\begin{array}{c}0.087 \\
(0.090)\end{array}$ & $\begin{array}{l}-0.072 \\
(0.083)\end{array}$ & $\begin{array}{c}0.178^{*} \\
(0.096)\end{array}$ \\
\hline Number of children $t-1$ & $\begin{array}{l}-0.185^{* * *} \\
(0.059)\end{array}$ & $\begin{array}{l}-0.029 \\
(0.060)\end{array}$ & $\begin{array}{l}-0.066^{*} \\
(0.038)\end{array}$ & $\begin{array}{l}-0.025 \\
(0.043)\end{array}$ \\
\hline In personal income $t-1$ & $\begin{array}{c}0.022 \\
(0.041)\end{array}$ & $\begin{array}{l}-0.030 \\
(0.044)\end{array}$ & $\begin{array}{l}-0.025 \\
(0.048)\end{array}$ & $\begin{array}{r}0.115^{*} \\
(0.063)\end{array}$ \\
\hline Employed $t-1$ & $\begin{array}{l}-0.261 * * * \\
(0.081)\end{array}$ & $\begin{array}{c}0.104 \\
(0.089)\end{array}$ & $\begin{array}{l}-0.117 \\
(0.093)\end{array}$ & $\begin{array}{l}-0.136 \\
(0.114)\end{array}$ \\
\hline Poor health scale $t-1$ & $\begin{array}{l}-0.085^{* * *} \\
(0.031)\end{array}$ & $\begin{array}{r}0.057^{*} \\
(0.034)\end{array}$ & $\begin{array}{c}0.014 \\
(0.037)\end{array}$ & $\begin{array}{l}-0.094^{* *} \\
(0.044)\end{array}$ \\
\hline Disabled $t-1$ & $\begin{array}{l}-0.033 \\
(0.069)\end{array}$ & $\begin{array}{l}-0.031 \\
(0.076)\end{array}$ & $\begin{array}{l}-0.096 \\
(0.079)\end{array}$ & $\begin{array}{l}-0.027 \\
(0.091)\end{array}$ \\
\hline Kessler distress scale $t-1$ & $\begin{array}{l}0.019^{* * *} \\
(0.006)\end{array}$ & $\begin{array}{c}0.009 \\
(0.007)\end{array}$ & $\begin{array}{l}0.014 * * \\
(0.007)\end{array}$ & $\begin{array}{l}0.036^{* * *} \\
(0.008)\end{array}$ \\
\hline $\begin{array}{l}\text { Psychological condition } \\
t-1\end{array}$ & $\begin{array}{l}-0.103 \\
(0.068)\end{array}$ & $\begin{array}{l}-0.186^{* *} \\
(0.076)\end{array}$ & $\begin{array}{l}-0.144 \\
(0.090)\end{array}$ & $\begin{array}{c}0.215^{*} \\
(0.118)\end{array}$ \\
\hline$\underset{t-1}{\text { Times } 5+\text { drinks per month }}$ & $\begin{array}{c}0.001 \\
(0.004)\end{array}$ & $\begin{array}{l}0.020^{* * *} \\
(0.004)\end{array}$ & $\begin{array}{c}0.004 \\
(0.007)\end{array}$ & $\begin{array}{l}0.020^{* * *} \\
(0.007)\end{array}$ \\
\hline Any marijuana use $t-1$ & $\begin{array}{r}0.130^{*} \\
(0.067)\end{array}$ & $\begin{array}{l}0.240^{* * *} \\
(0.072)\end{array}$ & $\begin{array}{l}0.248^{* *} \\
(0.099)\end{array}$ & $\begin{array}{c}0.132 \\
(0.108)\end{array}$ \\
\hline Incarcerated $t-1$ & $\begin{array}{c}0.212 \\
(0.181)\end{array}$ & $\begin{array}{c}0.215 \\
(0.176)\end{array}$ & $\begin{array}{c}0.384 \\
(0.438)\end{array}$ & $\begin{array}{c}0.186 \\
(0.423)\end{array}$ \\
\hline Any family contact $t-1$ & $\begin{array}{l}-0.064 \\
(0.088)\end{array}$ & $\begin{array}{l}-0.100 \\
(0.095)\end{array}$ & $\begin{array}{l}-0.107 \\
(0.121)\end{array}$ & $\begin{array}{c}0.101 \\
(0.140)\end{array}$ \\
\hline Any employed friends $t-1$ & $\begin{array}{c}0.016 \\
(0.065)\end{array}$ & $\begin{array}{l}-0.058 \\
(0.072)\end{array}$ & $\begin{array}{c}0.054 \\
(0.072)\end{array}$ & $\begin{array}{c}0.014 \\
(0.085)\end{array}$ \\
\hline Any homeless friends $t-1$ & $\begin{array}{l}-0.010 \\
(0.071)\end{array}$ & $\begin{array}{l}-0.047 \\
(0.078)\end{array}$ & $\begin{array}{c}0.120 \\
(0.085)\end{array}$ & $\begin{array}{c}0.135 \\
(0.098)\end{array}$ \\
\hline $\begin{array}{l}\text { Friends using drugs, } \\
\text { imprisoned } t-1\end{array}$ & $\begin{array}{c}0.050 \\
(0.067)\end{array}$ & $\begin{array}{l}-0.010 \\
(0.075)\end{array}$ & $\begin{array}{l}-0.031 \\
(0.086)\end{array}$ & $\begin{array}{r}0.171^{*} \\
(0.095)\end{array}$ \\
\hline $\begin{array}{l}\text { No observation (unit non- } \\
\text { response) in next wave }\end{array}$ & $\begin{array}{l}0.191^{*} \\
(0.107)\end{array}$ & $\begin{array}{l}-0.017 \\
(0.118)\end{array}$ & $\begin{array}{c}0.136 \\
(0.135)\end{array}$ & $\begin{array}{c}0.224 \\
(0.152)\end{array}$ \\
\hline Observations & \multicolumn{3}{|c|}{2486} & 89 \\
\hline
\end{tabular}


Note: Authors' estimates from probit models using unweighted data from the JH survey. Coefficients for intercepts, wave effects, and missing value indicators estimated but not shown. Standard errors are shown in parentheses, and estimated marginal effects are shown in italics. The estimated marginal effects are averages of effects calculated separately for each individual observation (averages of marginal effects rather than marginal effects calculated at the averages). * Significant at 0.10 level. $\quad * *$ Significant at 0.05 level. *** Significant at 0.01 level. 
TABLE 4

Housing Insecurity and Violence Bivariate Random-Effect Probit Model Results

\begin{tabular}{|c|c|c|c|c|}
\hline & \multicolumn{2}{|c|}{ Men } & \multicolumn{2}{|c|}{ Women } \\
\hline & $\begin{array}{l}\text { Housing } \\
\text { insecurity }\end{array}$ & Violence & $\begin{array}{l}\text { Housing } \\
\text { insecurity }\end{array}$ & Violence \\
\hline \multicolumn{5}{|l|}{ Lagged outcome measures } \\
\hline \multirow{3}{*}{$\begin{array}{l}\text { Housing insecure, no } \\
\text { violence } t-1\end{array}$} & $1.455 * * *$ & $0.233 *$ & $0.971 * * *$ & 0.104 \\
\hline & $(0.147)$ & $(0.122)$ & $(0.155)$ & $(0.132)$ \\
\hline & 0.316 & 0.042 & 0.189 & 0.016 \\
\hline \multirow{3}{*}{$\begin{array}{l}\text { Housing secure, violence } \\
t-1\end{array}$} & $0.484 * * *$ & $0.440 * * *$ & 0.173 & $0.397 * *$ \\
\hline & $(0.187)$ & $(0.148)$ & $(0.224)$ & $(0.160)$ \\
\hline & 0.098 & 0.086 & 0.029 & 0.072 \\
\hline \multirow{3}{*}{$\begin{array}{l}\text { Housing insecure, violence } \\
t-1\end{array}$} & $1.481 * * *$ & $0.431 * * *$ & $1.105^{* * *}$ & $0.593 * * *$ \\
\hline & $(0.196)$ & $(0.163)$ & $(0.242)$ & $(0.184)$ \\
\hline & 0.322 & 0.084 & 0.219 & 0.116 \\
\hline \multicolumn{5}{|l|}{ Other explanatory variables } \\
\hline \multirow{2}{*}{$\begin{array}{l}\text { Aboriginal or Torres Strait } \\
\text { Islander }\end{array}$} & -0.105 & -0.026 & 0.181 & 0.115 \\
\hline & $(0.175)$ & $(0.143)$ & $(0.191)$ & $(0.140)$ \\
\hline \multirow{2}{*}{$\begin{array}{l}\text { Migrated from non- } \\
\text { English country }\end{array}$} & -0.145 & $-0.695 * *$ & -0.214 & -0.047 \\
\hline & $(0.261)$ & $(0.278)$ & $(0.263)$ & $(0.203)$ \\
\hline \multirow[t]{2}{*}{ Bisexual, gay, or lesbian } & -0.128 & -0.311 & $0.512 * *$ & -0.099 \\
\hline & $(0.266)$ & $(0.231)$ & $(0.217)$ & $(0.160)$ \\
\hline \multirow{2}{*}{$\begin{array}{l}\text { Non-intact family at age } \\
\text { age } 14\end{array}$} & -0.044 & 0.033 & -0.124 & 0.030 \\
\hline & $(0.127)$ & $(0.103)$ & $(0.148)$ & $(0.108)$ \\
\hline \multirow{2}{*}{$\begin{array}{l}\text { In foster or institutional } \\
\text { care as child }\end{array}$} & 0.161 & -0.152 & -0.169 & -0.200 \\
\hline & $(0.149)$ & $(0.120)$ & $(0.171)$ & $(0.128)$ \\
\hline \multirow{2}{*}{$\begin{array}{l}\text { Childhood abuse and } \\
\text { neglect score }\end{array}$} & 0.080 & $0.239 * * *$ & -0.075 & $0.209 * * *$ \\
\hline & $(0.062)$ & $(0.052)$ & $(0.066)$ & $(0.050)$ \\
\hline \multirow[t]{2}{*}{ Homeless as child } & -0.104 & 0.033 & 0.223 & -0.055 \\
\hline & $(0.141)$ & $(0.115)$ & $(0.174)$ & $(0.127)$ \\
\hline \multirow{2}{*}{$\begin{array}{l}\text { Homeless before } J H \\
\text { survey }\end{array}$} & 0.341 & 0.109 & 0.276 & 0.234 \\
\hline & $(0.277)$ & $(0.227)$ & $(0.286)$ & $(0.262)$ \\
\hline \multirow{2}{*}{$\begin{array}{l}\text { Experienced violence before } \\
J H \text { survey }\end{array}$} & -0.074 & 0.113 & $0.395 * *$ & 0.141 \\
\hline & $(0.135)$ & $(0.116)$ & $(0.171)$ & $(0.130)$ \\
\hline \multirow{2}{*}{$\begin{array}{l}\text { Incarcerated before } J H \\
\text { survey }\end{array}$} & -0.024 & -0.0001 & -0.214 & 0.082 \\
\hline & $(0.130)$ & $(0.108)$ & $(0.217)$ & $(0.146)$ \\
\hline \multirow[t]{2}{*}{ Age } & -0.029 & -0.042 & $-0.120 * * *$ & -0.020 \\
\hline & $(0.032)$ & $(0.027)$ & $(0.041)$ & $(0.030)$ \\
\hline \multirow[t]{2}{*}{$\mathrm{Age}^{2} / 100$} & 0.039 & 0.032 & $0.147 * * *$ & 0.020 \\
\hline & $(0.040)$ & $(0.035)$ & $(0.052)$ & $(0.039)$ \\
\hline \multirow[t]{2}{*}{ 10-11 years of schooling } & 0.247 & -0.160 & -0.111 & 0.131 \\
\hline & $(0.181)$ & $(0.149)$ & $(0.210)$ & $(0.155)$ \\
\hline \multirow[t]{2}{*}{$12+$ years of schooling } & 0.141 & 0.001 & -0.145 & 0.129 \\
\hline & $(0.179)$ & $(0.147)$ & $(0.207)$ & $(0.152)$ \\
\hline
\end{tabular}




\begin{tabular}{|c|c|c|c|c|}
\hline College degree & $\begin{array}{c}0.023 \\
(0.352)\end{array}$ & $\begin{array}{l}-0.293 \\
(0.312)\end{array}$ & $\begin{array}{l}-0.038 \\
(0.386)\end{array}$ & $\begin{array}{c}0.212 \\
(0.270)\end{array}$ \\
\hline \multirow[t]{2}{*}{ Small city $t-1$} & 0.182 & $-0.341 * *$ & 0.313 & 0.070 \\
\hline & $(0.173)$ & $(0.151)$ & $(0.202)$ & $(0.162)$ \\
\hline \multirow[t]{2}{*}{ Rural area $t-1$} & -0.267 & -0.098 & 0.138 & 0.001 \\
\hline & $(0.249)$ & $(0.206)$ & $(0.292)$ & $(0.237)$ \\
\hline \multirow[t]{2}{*}{ In area rental price } & 0.381 & -0.095 & 0.500 & 0.396 \\
\hline & $(0.307)$ & $(0.260)$ & $(0.399)$ & $(0.312)$ \\
\hline \multirow[t]{2}{*}{ Unemployment rate } & -0.035 & -0.020 & 0.069 & 0.007 \\
\hline & $(0.039)$ & $(0.033)$ & $(0.046)$ & $(0.037)$ \\
\hline \multirow[t]{2}{*}{ Couple $t-1$} & -0.043 & 0.103 & -0.133 & $0.196^{*}$ \\
\hline & $(0.144)$ & $(0.118)$ & $(0.143)$ & $(0.112)$ \\
\hline \multirow[t]{2}{*}{ Number of children $t-1$} & $-0.296 * * *$ & -0.029 & $-0.160 * *$ & -0.038 \\
\hline & $(0.100)$ & $(0.077)$ & $(0.072)$ & $(0.051)$ \\
\hline \multirow[t]{2}{*}{ In personal income $t-1$} & 0.018 & -0.039 & -0.033 & $0.132 *$ \\
\hline & $(0.066)$ & $(0.053)$ & $(0.079)$ & $(0.072)$ \\
\hline \multirow[t]{2}{*}{ Employed $t-1$} & $-0.351 * * *$ & 0.127 & -0.206 & -0.133 \\
\hline & $(0.135)$ & $(0.113)$ & $(0.158)$ & $(0.131)$ \\
\hline \multirow[t]{2}{*}{ Poor health scale $t-1$} & $-0.127 * *$ & $0.073^{*}$ & 0.040 & $-0.104 * *$ \\
\hline & $(0.052)$ & $(0.043)$ & $(0.062)$ & $(0.051)$ \\
\hline \multirow[t]{2}{*}{ Disabled $t-1$} & -0.017 & -0.064 & -0.196 & -0.017 \\
\hline & $(0.115)$ & $(0.097)$ & $(0.134)$ & $(0.104)$ \\
\hline \multirow[t]{2}{*}{ Kessler distress scale $t-1$} & $0.038 * * *$ & 0.014 & $0.027 * *$ & $0.041 * * *$ \\
\hline & $(0.011)$ & $(0.009)$ & $(0.012)$ & $(0.010)$ \\
\hline \multirow{2}{*}{$\begin{array}{l}\text { Psychological condition } \\
t-1\end{array}$} & -0.209 & $-0.249 * *$ & $-0.317^{*}$ & $0.243 *$ \\
\hline & $(0.128)$ & $(0.108)$ & $(0.169)$ & $(0.142)$ \\
\hline \multirow{2}{*}{$\begin{array}{l}\text { Times } 5+\text { drinks per } \\
\text { month } t-1\end{array}$} & -0.0001 & $0.021 * * *$ & 0.010 & $0.022 * * *$ \\
\hline & $(0.007)$ & $(0.005)$ & $(0.012)$ & $(0.008)$ \\
\hline \multirow[t]{2}{*}{ Any marijuana use $t-1$} & $0.206^{*}$ & $0.281 * * *$ & $0.386^{* *}$ & 0.140 \\
\hline & $(0.116)$ & $(0.094)$ & $(0.171)$ & $(0.124)$ \\
\hline \multirow[t]{2}{*}{ Incarcerated $t-1$} & 0.303 & 0.156 & 0.421 & 0.227 \\
\hline & $(0.286)$ & $(0.215)$ & $(0.704)$ & $(0.470)$ \\
\hline \multirow[t]{2}{*}{ Any family contact $t-1$} & -0.070 & -0.127 & -0.136 & 0.128 \\
\hline & $(0.149)$ & $(0.120)$ & $(0.196)$ & $(0.157)$ \\
\hline \multirow[t]{2}{*}{ Any employed friends $t-1$} & 0.044 & -0.040 & 0.167 & 0.032 \\
\hline & $(0.108)$ & $(0.091)$ & $(0.121)$ & $(0.097)$ \\
\hline \multirow[t]{2}{*}{ Any homeless friends $t-1$} & 0.004 & -0.048 & 0.171 & 0.130 \\
\hline & $(0.115)$ & $(0.095)$ & $(0.136)$ & $(0.109)$ \\
\hline \multirow{2}{*}{$\begin{array}{l}\text { Friends using drugs, } \\
\text { imprisoned } t-1\end{array}$} & 0.079 & -0.014 & -0.109 & 0.169 \\
\hline & $(0.111)$ & $(0.093)$ & $(0.144)$ & $(0.108)$ \\
\hline \multirow{2}{*}{$\begin{array}{l}\text { No observation (unit non- } \\
\text { response) in next wave }\end{array}$} & $0.292 *$ & -0.017 & 0.174 & 0.236 \\
\hline & $(0.171)$ & $(0.144)$ & $(0.216)$ & $(0.171)$ \\
\hline \multirow{2}{*}{$\begin{array}{l}\text { Serial correlation in } \\
\text { unobserved components }\end{array}$} & $0.274 * * *$ & $0.270 * * *$ & $0.260 * * *$ & $0.151 * * *$ \\
\hline & $(0.060)$ & $(0.058)$ & $(0.063)$ & $(0.058)$ \\
\hline $\begin{array}{l}\text { Correlation between } \\
\text { random effects }\left(\rho_{\eta \mu}\right)\end{array}$ & \multicolumn{2}{|c|}{$\begin{array}{c}0.026 \\
(0.151)\end{array}$} & \multicolumn{2}{|r|}{$\begin{array}{c}0.275 \\
(0.214)\end{array}$} \\
\hline
\end{tabular}



Correlation between
$0.241 * * *$
$0.181 * * *$
time-varying errors $\left(\rho_{e u}\right)$
(0.056)
$(0.069)$
Observations
2,486
1,989

Note: Authors' estimates from bivariate, random-effect probit models (see equations (1)-(5)) using unweighted data from the JH survey. Coefficients for intercepts, wave effects, and missing value indicators and models (4) and (5) for initial conditions estimated but not shown. Standard errors are shown in parentheses, and estimated marginal effects are shown in italics. The estimated marginal effects are averages of effects calculated separately for each individual observation (averages of marginal effects rather than marginal effects calculated at the averages).

* Significant at 0.10 level. $\quad * *$ Significant at 0.05 level. $\quad * * *$ Significant at 0.01 level. 
TABLE 5

Housing Insecurity and Violence Bivariate Random-Effect Probit Model Results—Alternative Definitions of Violence and Housing insecurity and Alternative lags

\begin{tabular}{|c|c|c|c|c|}
\hline & \multicolumn{2}{|c|}{ Men } & \multicolumn{2}{|c|}{ Women } \\
\hline & H. insecurity & Violence & H. insecu & Violenc \\
\hline \multicolumn{5}{|c|}{ Violence includes assaults and robberies reported to police } \\
\hline & \multicolumn{2}{|c|}{ (a) } & \multicolumn{2}{|c|}{ (b) } \\
\hline $\begin{array}{l}\text { Housing insecure, no } \\
\text { violence } t-1\end{array}$ & $\begin{array}{l}1.423 * * * \\
(0.151) \\
0.310\end{array}$ & $\begin{array}{c}0.221^{*} \\
(0.115) \\
0.045\end{array}$ & $\begin{array}{l}1.016^{* * *} \\
(0.156) \\
0.196\end{array}$ & $\begin{array}{c}0.184 \\
(0.122) \\
0.036\end{array}$ \\
\hline $\begin{array}{l}\text { Housing secure, violence } \\
t-1\end{array}$ & $\begin{array}{r}0.321^{*} \\
(0.175)\end{array}$ & $\begin{array}{l}0.277 * * \\
(0.137)\end{array}$ & $\begin{array}{c}0.255 \\
(0.203)\end{array}$ & $\begin{array}{l}0.320 * * \\
(0.138)\end{array}$ \\
\hline $\begin{array}{l}\text { Housing insecure, } \\
\text { violence } t-1\end{array}$ & $\begin{array}{l}0.064 \\
1.452^{* * *} \\
(0.187) \\
0.316\end{array}$ & $\begin{array}{l}0.058 \\
0.505^{* * *} \\
(0.148) \\
0.113\end{array}$ & $\begin{array}{l}0.043 \\
1.019^{* * *} \\
(0.227) \\
0.197\end{array}$ & $\begin{array}{l}0.066 \\
0.578^{* * *} \\
(0.164) \\
0.131\end{array}$ \\
\hline $\begin{array}{l}\text { Serial correlation in } \\
\text { unobserved } \\
\text { components }\end{array}$ & $\begin{array}{l}0.279^{* * *} \\
(0.060)\end{array}$ & $\begin{array}{l}0.251^{* * *} \\
(0.056)\end{array}$ & $\begin{array}{l}0.261 * * * \\
(0.062)\end{array}$ & $\begin{array}{l}0.131^{* * *} \\
(0.049)\end{array}$ \\
\hline $\begin{array}{l}\text { Correlation between } \\
\text { random effects }\left(\rho_{\eta \mu}\right)\end{array}$ & & & & \\
\hline $\begin{array}{l}\text { Correlation between } \\
\text { time-var. errors }\left(\rho_{e u}\right)\end{array}$ & & $\begin{array}{l}y^{* * *} \\
3)\end{array}$ & & $\begin{array}{l}53 * * \\
55)\end{array}$ \\
\hline Observations & & 81 & & 88 \\
\hline
\end{tabular}

Housing insecurity redefined as literal homelessness

(c)

(d)

$\begin{array}{ccccc}\text { Housing insecure, no } & 1.613^{* * *} & 0.215 & 1.420^{* * *} & 0.191 \\ \text { violence } t-1 & (0.268) & (0.169) & (0.176) & (0.183) \\ & 0.200 & 0.043 & 0.220 & 0.035 \\ \text { Housing secure, violence } & 0.164 & 0.401^{* * *} & 0.560^{* * *} & 0.682^{* * *} \\ t-1 & (0.203) & (0.124) & (0.163) & (0.102) \\ & 0.011 & 0.085 & 0.046 & 0.156 \\ \text { Housing insecure, } & 1.442^{* * *} & 0.173 & 1.705^{* * *} & 0.896^{* * *} \\ \text { violence } t-1 & (0.309) & (0.220) & (0.244) & (0.210) \\ & 0.168 & 0.034 & 0.307 & 0.211 \\ \text { Serial correlation in } & 0.089 & 0.221^{* * *} & - & - \\ \text { unobs. components } & (0.113) & (0.060) & & - \\ \text { Correlation between } & & 0.128 & & - \\ \text { random effects }\left(\rho_{\eta \mu}\right) & & (0.198) & & - \\ \text { Correlation between } & & 0.169^{* *} & & \end{array}$


Observations

Specification with two lags

$\begin{array}{ccccc}\text { Housing insecure, no } & 1.719^{* * *} & 0.138 & 1.218^{* * *} & 0.061 \\ \text { violence } t-1 & (0.132) & (0.110) & (0.156) & (0.133) \\ & 0.417 & 0.026 & 0.265 & 0.010 \\ \text { Housing insecure, no } & 0.455^{* * *} & 0.006 & 0.148 & -0.059 \\ \text { violence } t-2 & (0.148) & (0.109) & (0.174) & (0.129) \\ & 0.098 & 0.001 & 0.028 & -0.010 \\ \text { Housing secure, violence } & 0.426^{* *} & 0.688^{* * *} & 0.296 & 0.396^{* *} \\ t-1 & (0.183) & (0.148) & (0.218) & (0.165) \\ & 0.088 & 0.163 & 0.053 & 0.074 \\ \text { Housing secure, violence } & -0.132 & 0.263 & 0.464 * * & 0.068 \\ t-2 & (0.194) & (0.166) & (0.211) & (0.183) \\ & -0.027 & 0.056 & 0.092 & 0.012 \\ \text { Housing insecure, } & 1.752^{* * *} & 0.531 * * * & 1.502 * * * & 0.593 * * * \\ \text { violence } t-1 & (0.178) & (0.148) & (0.241) & (0.186) \\ & 0.425 & 0.119 & 0.338 & 0.121 \\ \text { Housing insecure, } & 0.358^{*} & 0.544 * * * & 0.338 & 0.270 \\ \text { violence } t-2 & (0.190) & (0.156) & (0.244) & (0.197) \\ & 0.076 & 0.129 & 0.066 & 0.051 \\ \text { Serial correlation in } & 0.025 & 0.037 & 0.055 & 0.038 \\ \text { unobs. components } & (0.024) & (0.040) & (0.049) & (0.044) \\ \text { Correlation between } & & 0.208^{* *} & & 0.190 \\ \text { random effects }\left(\rho_{\eta \mu}\right) & & (0.101) & & (0.129) \\ \text { Correlation between } & & 0.187 * * * & & 0.180^{* * *} \\ \text { time-var. errors }\left(\rho_{e u}\right) & & (0.051) & 0.066) \\ \text { Observations } & & 1,881 & 1,521\end{array}$

Note: Authors' estimates from bivariate, random-effect probit models (see equations (1)-(5)) using unweighted data from the JH survey for panels (a)-(e), specified as in Table 4. Estimates from probit models for panel (f), specified as in Table 3. Standard errors are shown in parentheses, and estimated marginal effects are shown in italics. The estimated marginal effects are averages of effects calculated separately for each individual observation (averages of marginal effects rather than marginal effects calculated at the averages).

* Significant at 0.10 level. $\quad * *$ Significant at 0.05 level. $\quad * * *$ Significant at 0.01 level. 
APPENDIX A

Means of Explanatory Variables in Longitudinal Analysis Sample

\begin{tabular}{|c|c|c|}
\hline & Men & Women \\
\hline Aboriginal or Torres Strait Islander & 0.136 & 0.158 \\
\hline Migrated from non-English country & 0.058 & 0.081 \\
\hline Bisexual, gay, or lesbian & 0.053 & 0.106 \\
\hline Non-intact family at age 14 & 0.492 & 0.575 \\
\hline In foster or institutional care as child & 0.234 & 0.231 \\
\hline Childhood abuse, neglect score (0-4) & 1.347 & 1.440 \\
\hline Childhood abuse information missing & 0.028 & 0.052 \\
\hline Homeless as child & 0.418 & 0.410 \\
\hline Homeless before Journeys Home survey & 0.947 & 0.931 \\
\hline Experienced violence before Journeys Home survey & 0.652 & 0.624 \\
\hline Incarcerated before Journeys Home survey & 0.466 & 0.125 \\
\hline Age & 35.866 & 33.314 \\
\hline $10-11$ years of schooling & 0.358 & 0.348 \\
\hline $12+$ years of schooling but no college degree & 0.461 & 0.462 \\
\hline College degree & 0.037 & 0.040 \\
\hline Small city $t-1$ & 0.157 & 0.138 \\
\hline Rural area $t-1$ & 0.043 & 0.043 \\
\hline Area weekly rental price & 338.209 & 327.687 \\
\hline Unemployment rate & 5.703 & 5.891 \\
\hline Couple $t-1$ & 0.187 & 0.243 \\
\hline Number of children $t-1$ & 0.191 & 0.817 \\
\hline Personal income $t-1$ & 456.227 & 493.670 \\
\hline Personal income missing $t-1$ & 0.041 & 0.030 \\
\hline Employed $t-1$ & 0.292 & 0.232 \\
\hline Poor health scale (1-5) $t-1$ & 3.136 & 3.166 \\
\hline Disabled $t-1$ & 0.491 & 0.454 \\
\hline Disabled information missing $t-1$ & 0.008 & 0.011 \\
\hline Kessler distress scale $(0-24) t-1$ & 7.623 & 8.435 \\
\hline Psychological condition $t-1$ & 0.642 & 0.735 \\
\hline Psychological condition information missing $t-1$ & 0.033 & 0.028 \\
\hline Times consuming $5+$ drinks per month $t-1$ & 4.412 & 2.015 \\
\hline Drinking information missing $t-1$ & 0.014 & 0.008 \\
\hline Any marijuana use $t-1$ & 0.362 & 0.155 \\
\hline Incarcerated $t-1$ & 0.027 & 0.005 \\
\hline Any family contact $t-1$ & 0.868 & 0.916 \\
\hline Any employed friends $t-1$ & 0.640 & 0.579 \\
\hline Any homeless friends $t-1$ & 0.226 & 0.194 \\
\hline Friends using drugs, arrested or imprisoned $t-1$ & 0.446 & 0.252 \\
\hline Wave (2-6) & 3.809 & 3.841 \\
\hline Person/wave observations & 2,486 & 1,989 \\
\hline
\end{tabular}

This article is protected by copyright. All rights reserved. 
Note: The tables report averages of the listed variables that were calculated using unweighted longitudinal data from the JH survey. 


\section{University Library}

\section{- M M I E E R VA A gateway to Melbourne's research publications}

Minerva Access is the Institutional Repository of The University of Melbourne

Author/s:

Diette, TM;Ribar, DC

Title:

A LONGITUDINAL ANALYSIS OF VIOLENCE AND HOUSING INSECURITY

Date:

2018-07-01

Citation:

Diette, T. M. \& Ribar, D. C. (2018). A LONGITUDINAL ANALYSIS OF VIOLENCE

AND HOUSING INSECURITY. ECONOMIC INQUIRY, 56 (3), pp.1602-1621. https:// doi.org/10.1111/ecin.12571.

Persistent Link:

http://hdl.handle.net/11343/283727 